\title{
Citizenship and COVID-19: Syndemic Effects
}

\author{
Jo Shaw ${ }^{1}$ (D) \\ ${ }^{1}$ School of Law, University of Edinburgh, Edinburgh, United Kingdom \\ Corresponding author: jo.shaw@ed.ac.uk
}

(Received 03 September 2021; accepted 13 September 2021)

\begin{abstract}
This article begins the task of outlining the impacts of the COVID-19 pandemic in relation to matters of citizenship, using what is termed a "syndemic analysis." This type of analysis places both the pandemic and citizenship in their wider contexts. The synergistic or intersectional thinking encouraged by the characterization of the pandemic as a syndemic, which links together health, socio-economic issues, and political questions, is useful for highlighting how much more vulnerable to many of the negative impacts of the pandemic in the sphere of citizenship are those who are also more vulnerable both to catching and suffering more seriously from the virus and to experiencing negatively the externalities of the measures taken to restrict social contact by shutting down economies. While the scope of the review is relatively broad and encompasses many different domains of "pandemic life," what emerges from the analysis are important insights into how many of the impacts of the pandemic in fact operate at the intersection of citizenship and constitutional law and thus play out in the form of changes in relation to constitutional citizenship, both as ideal and as practice. The article takes an important step towards developing the use of constitutional citizenship as a framing device for understanding citizenship as putative full membership in a given society.
\end{abstract}

Keywords: Citizenship; pandemic; syndemic; constitution; COVID19

\section{A. Introduction}

This article studies the impact of the COVID-19 pandemic in the domain of citizenship. It highlights how the pandemic enhances existing vulnerabilities and inequalities and thus undermines ideas, concepts, and practices of membership, especially for some individuals and groups, and suggests areas where strengthening citizenship may also be a strategy for effective recovery after the pandemic. The article combines reflections on the pandemic, which has triggered crises of governance, public health, and economic wellbeing, with an articulation of the idea and ideal of constitutional citizenship as a place where the symbolism of (in)equality is rife. The urgency of the analysis is driven by the significance that citizenship, as membership, can take on in the context of crisis, especially when it becomes a strong marker of entitlement and belonging. Furthermore, citizenship is not only a legal and socio-economic issue but also a proxy for political questions about legitimate responses to both a public health emergency and its longer term societal and

\footnotetext{
Acknowledgements: I am grateful to a number of colleagues who have read versions of my ruminations on citizenship and the pandemic including Jelena Džankić, Jacob Eisler, and Martijn van den Brink. I am additionally grateful to colleagues for their comments on presentations on Citizenship and COVID-19 made at Edinburgh Law School, Maxwell School of Citizenship, Syracuse, and IFDT Belgrade.
} 
economic consequences. While the approach is not strictly comparative, the article draws on examples to be found in many different countries, reflecting the global nature of the pandemic. ${ }^{1}$

For a brief moment, it was suggested that the COVID-19 pandemic could be a great "leveler." SARS-COV-2 is a novel virus in humans to which all could be susceptible. In fact, from the inception of the pandemic, it quickly emerged that the impacts upon humans of the virus, of the disease to which it gives rise, and of the measures that are taken to control its spread are uneven and are conditioned by a variety of physical and social vectors. These include age, socio-economic status, disability, presence of co-morbidities (including ones which are strongly correlated with poverty such as obesity and various heart and pulmonary diseases), race, and ethnic origin. Roshni Chakraborty and Jacqueline Bhabha make the point in these terms: ${ }^{3}$

Far from being "great equalizers," diseases reflect and reinforce preexisting hierarchies. Structural inequalities in wealth, housing, health care, employment, and social capital place the poor and the socially vulnerable at a higher risk of infection and death. At the same time, the fear and suspicion engendered by epidemics exacerbate the vulnerabilities of those perceived as "other" or "outsider", populations whose survival and dignity are already compromised by social exclusion mechanisms such as legal invisibility, geographic ghettoization, and social ostracism.

Take the case of Black and minority ethnic ("BAME") communities in the Global North. ${ }^{4}$ Members of these groups are heavily represented within "frontline worker" roles exposed to increased infection risk, often without effective protective equipment. Infection with the virus amongst these groups seems more likely to lead to severe disease and mortality. Finally, the socio-economic consequences of economic shutdowns or "lockdowns" are inevitably more serious within communities which have already been negatively impacted by the long tail of the great recession at the end of the 2000s and the beginning of the 2010s, and the austerity which was a dominant political and economic response to that crisis. ${ }^{5}$ Once again, BAME individuals are overrepresented within these groups in many countries, and these groups will feel the sting of

\footnotetext{
${ }^{1}$ The COVID-19 pandemic has given rise to an unprecedented data gathering exercise across many domains, including law and policy, as well as a number of "rapid reaction" collections of articles based on national reports. Databases of legal and policy measures include: (1) COVID-19 Government Response Tracker, UNIV. OxFORD, https://www.bsg.ox.ac.uk/research/research-projects/ covid-19-government-response-tracker; Thomas Hale, Noam Angrist, Refael Goldszmidt, Beatriz Kira, Anna Petherick, Toby Philips, Samuel Webster, Emily Cameron-Blake, Laura Hallas, Saptarshi Majumdar, \& Helen Tatlow, A Global Panel Database of Pandemic Policies (Oxford COVID-19 Government Response Tracker), 5 NATURE Hum. BeHAV. 529 (2021), https://www. nature.com/articles/s41562-021-01079-8; (2) CoronaNet Research Project, PERISCOPE CONSORTIUM, https://www.coronanetproject.org; Cindy Cheng, Joan Barcelo, Allison Spencer Hartnett, Robert Kuinec, \& Luca Messerschmidt, COVID-19 Government Response Event Dataset (CoronaNet v.1.0), 4 NATURE HuM. BeHAV. 756 (2020), https://doi.org/10.1038/s41562020-0909-7; and (3) COVID-19 Law Lab, WORLD HEALTH ORGANIZATION, https://covidlawlab.org. See "rapid reaction" surveys of legislative and regulatory responses to the COVID-19 pandemic like UCL, Oxford Compendium of Nat'l Legal Responses to Covid-19, https://lexatlas-c19.org, and materials published on the Verfassungsblog in 2020 and 2021. For a 2021 summary, see Joelle Grogan, Power, Law and the COVID-19 Pandemic - Part II: Preparing for Future Emergencies, VerfBLOG (May 15, 2021), https://verfassungsblog.de/power-law-and-the-covid-19-pandemic-part-ii.

${ }^{2}$ To understand the truly global nature of the COVID-19 pandemic as public health emergency (cases, deaths, vaccines, etc.) it is possible to consult one of several data repositories, such as Our World in Data, Global Change Data Lab, https:// ourworldindata.org/coronavirus, or Coronavirus Data Res. Ctr., JoHns Hopkins UnIV. \& MeD., https://coronavirus.jhu. edu. For a library of COVID-19 trackers, see COVID19 Trackers Library, https://dbhatedin.github.io/CuratedTrackersLibrary.

${ }^{3}$ Roshni Chakraborty \& Jacqueline Bhabha, Fault Lines of Refugee Exclusion: Statelessness, Gender, and COVID-19 in South Asia, 23 HeAlth \& Hum. RTs. J. 237, 238 (2021).

${ }^{4}$ For a review of the available literature, see Peter Phiri, Gayathri Delanerolle, Ayaat Al-Sudani, \& Shanaya Rathod, COVID-19 and Black, Asian, and Minority Ethnic Communities: A Complex Relationship Without Just Cause, 7 J. MED. Internet Res. Pub. Health Surveillance e22581 (Feb. 2021), https://publichealth.jmir.org/2021/2/e22581.

${ }^{5}$ Zoë Irving, The Legacy of Austerity, 20 Soc. POL'y AND Soc'y 97-110 (2021); UN Special Rapporteur on Extreme Poverty and Hum. Rights, Looking Back to Look Ahead: A Rights-based Approach to Social Protection in the Post-COVID-19 Economic Recovery (Sept. 11, 2020), https://www.ohchr.org/Documents/Issues/Poverty/covid19.pdf.
} 
increased income inequality after the pandemic. ${ }^{6}$ All of these factors add up to a poor outcome for many members of these communities, in terms of the impact of both the disease itself and the "pandemic conditions" to which it has given rise. ${ }^{7}$

COVID-19 also highlights differences between countries in the Global North and Global South as to the resources available to combat the spread of a virus which requires social and physical distancing, to provide effective therapies, and to enable the equitable distribution of effective vaccines, not to mention differences as to the availability of comprehensive healthcare and frameworks for social protection. The latter are unattainable for lower income countries. Yet the younger age profile of populations in many lower income countries seems to have had significant implications for the mortality rate, at least in some places and at some points, despite the delays in vaccine distribution in the Global South. However, it will be many years before it is possible to draw firm conclusions on the direct and indirect outcomes of the pandemic as virus and of the responses to the pandemic across different countries ${ }^{8}$ or to benchmark with certainty the effectiveness of different responses. ${ }^{9}$

One way of articulating the differential impact of SARS-COV-2 and other viruses across communities and countries is to employ the term syndemic alongside that of pandemic. ${ }^{10}$ According to Merrill Singer, who pioneered this term,

A syndemic . . . involves a set of enmeshed and mutually enhancing health problems that, working together in a context of noxious social and physical conditions, can significantly affect the overall disease burden and health status of a population. ${ }^{11}$

Singer argues that COVID-19 should be characterized as a syndemic. As quoted in the Financial Times, he states that "we have to consider not just biological issues but the social structural forces that propel disease interaction, population vulnerability and unequal access to healthcare, including [...] Covid-19 vaccines." 12 In other words, we will only fully understand the nature and effects of the pandemic, and especially the documented inequality of outcomes, when we study the virus

\footnotetext{
${ }^{6}$ Angus Deaton, Covid Shows How the State Can Address Social Inequality, THe FinanCial Times (Jan. 5, 2021), https://www. ft.com/content/caa37763-9c71-4f8d-9c29-b16ccf53d780; Francisco Ferreira, Inequality in the Time of COVID-19, IMF FIN. AND DEV. 20 (Summer 2021), https://www.imf.org/external/pubs/ft/fandd/2021/06/inequality-and-covid-19-ferreira.htm.

${ }^{7}$ Ali Cheshmehzangi, Vulnerability of the UK's BAME Communities During COVID-19: The Review of Public Health and Socio-economic Inequalities, J. Hum. BeHAV. Soc. Env'T (2021); Clarence C. Gravlee, Systemic Racism, Chronic Health Inequities, and COVID-19: A Syndemic in the Making?, AM. J. Hum. Biology 32:e23482 (2020), https://www.ncbi.nlm. nih.gov/pmc/articles/PMC7441277/. On the relationship between COVID-19 and settler colonialism, see Monika Batra Kashyap, U.S. Settler Colonialism, White Supremacy, and the Racially Disparate Impacts of COVID-19, 11 CAL. L. REV. ONLINE 517-529 (2020), https://digitalcommons.law.seattleu.edu/faculty/830/. See also Luis Alberto Martinez-Juarez, Ana Cristina Sedas, Miriam Orcutt, \& Raj Bhopal, Governments and International Institutions Should Urgently Attend to the Unjust Disparities that COVID-19 is Exposing and Causing, 23 ECLINICALMEDICINE 100376 (2020).

${ }^{8}$ Jonathan M. Clarke, Azeem Majeed, Thomas Beaney, Measuring the Impact of COVID-19, BMJ 373, 1239 (2021), https:// www.bmj.com/content/373/bmj.n1239. On the distinction between the virus and responses to the pandemic, see J. Michael Ryan, The SARS-CoV-2 Virus and the COVID-19 Pandemic, in COVID-19: VOl. II: SOCIAL CONSEQUENCES AND CUltural ADAPTATIONS 9 (2020).

${ }^{9}$ Sheila Jasanoff \& Stephen Hilgartner: A Stress Test for Politics: Insights from the Comparative Covid Response Project (CompCoRe) 2020, VERFBLOG (May 11, 2021), https://verfassungsblog.de/a-stress-test-for-politics-insights-from-the-comparative-covid-responseproject-compcore-2020.

${ }^{10}$ In any event, a pandemic is easier to describe-for example, by reference to the spread of a particular disease across borders-than it is to define. See Peter Doshi, The Elusive Definition of Pandemic Influenza, Bulletin of the World Health Organization 89.7, 532-8 (2011). The outbreak of COVID-19 was confirmed as a pandemic by the World Health Organization on March 11, 2020, by which time there were cases in more than one hundred countries across the world. See Coronavirus Confirmed as Pandemic by World Health Organization, BBC News (Mar. 11, 2020), https://www.bbc.co. uk/news/world-51839944.

${ }^{11}$ Merrill Singer, Introduction to Syndemics: A Critical Systems Approach to Public and Community Health xiv (John Wiley \& Sons, Inc. 2009).

${ }^{12}$ Anjana Ahuja, Covid-19 is Really a Syndemic_and That Shows Us How to Fight It, Fin. Times (Oct. 9, 2020), https://www. ft.com/content/34a502b1-5665-42ff-8a8d-1298b71f1eb.
} 
and the disease it engenders together with ("syn") other issues, such as its wider social and political context. It is the interaction between disease and context that helps to explain not only the "what" regarding the disparate impacts of the pandemic but also something about the puzzle of how and why this happens.

Since the inception of the pandemic, an increasing number of studies have exploited similar synergistic thinking. These studies have explored, amongst other matters, the gendered ${ }^{13}$ and racialized $^{14}$ nature of the virus' impact and its exclusionary effects (for example, in relation to working from home and the continued unequal division of domestic labor and now homeschooling), ${ }^{15}$ the different types of forced migrations which are occurring as well as the exclusionary effects of border closures, ${ }^{16}$ the challenge of keeping open the routes towards regularization and safe-settlement for asylum seekers and other displaced persons, ${ }^{17}$ alongside the negative impacts of the pandemic on stateless individuals and groups ${ }^{18}$ and on minorities such as the Roma. ${ }^{19}$ Inequality and vulnerability have been common themes, even though these are not concepts that are either easy to define or uncontested. ${ }^{20}$ In such cases, the issues under scrutiny can be characterized as dimensions of citizenship, understood as issues of status and rights for members of a given polity, defining in many respects how we live within bounded communities and also what the consequences of these boundaries are for non-members. In many cases, the work can also be described as "intersectional" insofar as it focuses on the "interconnected nature of social categorizations such as race, class, and gender, regarded as creating overlapping and interdependent systems of discrimination or disadvantage" 21 with regard to issues of membership. ${ }^{22}$

It has been argued that the use of the term "citizenship" in these types of cases is problematic as it has little explanatory purchase. ${ }^{23}$ This article rejects that contention and argues that citizenship properly understood provides both a suitable object of study, illuminating many of the ways in which the syndemic/pandemic impacts our lives, as well as an appropriate framing for contestations of the exclusionary effects of COVID-19. Such an analysis can be undertaken using the

\footnotetext{
${ }^{13}$ In the United Kingdom, see Clare Wenham \& Asha Herten-Crabb, Why We Need a Gender Advisor on SAGE, 1(4) London School Econ. Pub. Pol'y Rev. 7 (2021), http://doi.org/10.31389/lseppr.25; in the Global South, see Nadje Al-Ali, Covid-19 and Feminism in the Global South: Challenges, Initiatives and Dilemmas, 27 EUR. J. WOMEN's STUD. 333 (2020).

${ }^{14}$ Amanuel Elias, Jehonathan Ban, Fethi Mansouri, \& Yin Paradies, Racism and Nationalism During and Beyond the COVID-19 Pandemic, 44(5) ETHNiC \& RaCial Stud. 783 (2021).

${ }^{15}$ Kate Power, The COVID-19 Pandemic Has Increased the Care Burden of Women and Families, 16 SusTAINABILITY: SCI., PRAC. \& POL'y 67 (2020).

${ }^{16} \mathrm{See}$, for example, the closing of the Nepal-India border. See also Nimesh Dhungana, Human Dignity and Cross-border Migrants in the Era of the COVID-19 Pandemic, 136 WorLd DEV. 105174 (2020).

${ }^{17}$ See, for example Gillian Triggs, We Can Secure Both Public Health and the Rights of Asylum Seekers to Protection, 32(2) InT'L J. Refugee L. 367 (2020); Nasar Meer, Emma Hill, Timothy Peace \& Leslie Villegas, Rethinking Refuge in the Time of COVID-19, 44(5) ETHNic \& Racial STUd. 864 (2021).

${ }^{18}$ ISI and ENS work. See, e.g. Tejal Khanna, Addressing COVID-ified Maritime Migration in the Bay of Bengal: The Case of Stateless Rohingya Boat People, 12(3) Austl. J. Mar. \& OcEAn AfF. 181 (2020).

${ }^{19}$ Andreea Cârstocea, Raul Carstocea \& Craig Willis, The Impact of COVID-19 on Roma Communities in Non-EU Countries in Eastern Europe, ECMI MinORITIES BLOG (Oct. 5, 2020), https://www.ecmi.de/infochannel/detail/the-impact-of-covid-19on-roma-communities-in-non-eu-countries-in-eastern-europe.

${ }^{20}$ For example, although widely used, including in the COVID-19 context, "vulnerability" is a contested and arguably political term insofar as it may also produce a sense of "othering" as individuals and groups are "vulnerabilized." See Kate Brown, Kathryn Ecclestone, \& Nick Emmel, The Many Faces of Vulnerability, 16 Soc. POL'Y \& SOC’Y 497 (2017); Lindsay Larios \& Stephanie Paterson, Fear of the Other: Vulnerabilization, Social Empathy, and the COVID-19 Pandemic in Canada, 15(2) CRITICAL POL'Y STUD. 137 (2021).

${ }^{21}$ Intersectionality, OXFORD ENGLISH Dictionary (2d ed. 1989). Above all, intersectionality is a theoretical and scholarly approach to cumulative inequalities pioneered by Kimberlé Crenshaw.

${ }^{22}$ For an example of an intersectional approach to COVID-19, see Giorgia Donà Race, Immigration and Health: The Hostile Environment and Public Health Responses to Covid-19, 44(5) Ethnic \& Racial Stud. 906 (2021).

${ }^{23}$ Brooke A. Ackerly, Elisabeth Jay Friedman, Krishna Menon, Marysia Zalewski, \& Meenakshi Gopinath, COVID-19: Shifting Paradigms, 22(4) INT'L Feminist J. POL. 453 (2020).
} 
prism of constitutional citizenship, understood as the space where constitutions and citizenship intersect. ${ }^{24}$ As with analysis of the pandemic, our understanding of constitutional citizenship emerges most clearly from synergistic analysis which places legal norms, such as the constitutionally determined equality of citizens, alongside other norms and principles that govern the core aspects of human and political sociality that citizenship embodies. The benefit of such an approach is that it allows us to exploit the uneasy relationships between citizenship, (in)equality, and in/exclusion in ways that can shed new light on how the pandemic has come to have such serious impacts upon certain communities and groups, especially those that are vulnerable. Furthermore, this mode of analysis may even suggest pathways towards fresh legal and political contestations of the weary inevitability that somehow a pandemic such as COVID-19 is bound to have the most negative effects for those who already live in challenging circumstances and that in the face of such a crisis nothing will change.

The next section of the article elaborates further upon the basic idea of constitutional citizenship before subsequent sections explore a variety of domains in which we can see an impact of the pandemic on aspects of constitutional citizenship. This analysis makes no claim to completeness, and provides, at this stage, only preliminary reflections. The reflections are organized under the following headings: citizenship as legal status; pandemic (im)mobilities; intrusions in private life; the side-lining of political citizenship; and the challenge of protecting the vulnerable during a pandemic. The analysis highlights that while some impact upon citizenship status and rights might be thought inevitable in a pandemic, it is the extent to which such impacts can be exacerbated by existing vulnerabilities or inequalities which is the most important feature to emphasize. As already hinted, the article juggles the paradox that citizenship can be both object of study and analytical tool. Indeed, as will be shown, the conceptual lenses of constitutional citizenship provide a powerful framing to analyze the disparate impacts of the pandemic in a way that offers both diagnosis of areas of concern and new ways of challenging the status quo.

\section{B. Values, Principles, and Constitutional Citizenship}

The type of equal citizenship trumpeted in many constitutions across the world is just as elusive as the idea of an equal opportunity pandemic. Formal constitutional law in many countries asserts the equality of citizens, often alongside the imperative of avoiding statelessness. This may be found in the texts of constitutions themselves and in principles found elsewhere within constitutional law, many of which have been interpreted and upheld by courts with constitutional mandates. ${ }^{25}$ Such texts may promise equal citizenship for all, but the reality, once context is brought back in, is that citizenship is often experienced unequally. This point applies across citizenship's many dimensions: as regards issues of legal status or "access," often termed "nationality"; as regards the bundle of rights and duties that are sometimes conflated with the membership principle itself; and as regards the political, identarian, and symbolic aspects of citizenship and its capacity to define who "we" are and how we can act responsibly towards each other and towards the institutions that shape our common existence. In sum, "full membership" may be inaccessible for many, both for reasons of socio-economic exclusion and because of the inaccessibility of public spaces for political participation.

Inequality has long been a pervasive condition of citizenship and of citizens both within and across states, ${ }^{26}$ but it has perhaps become even more visible in recent years, in tandem with a noticeable rise in political movements of nationalism, populism, and often authoritarianism,

\footnotetext{
${ }^{24}$ Jo Shaw, The People in Question: Citizens and Constitutions in Uncertain Times (Bristol Univ. Press 2020). Jo Shaw, Introduction to the GLOBALCIT symposium, (2021), https://globalcit.eu/globalcit-review-symposium-of-thepeople-in-question-citizens-and-constitutions-in-uncertain-times-jo-shaw.

${ }^{25}$ Jo Shaw, The People in Question: Citizens and Constitutions in UnCertain Times 77-87, n.22 (Bristol Univ. Press 2020).

${ }^{26}$ Ayelet Shachar, The Birthright Lottery: Citizenship and Global Inequality (Harvard Univ. Press 2009).
} 
which have been infecting many national citizenship regimes. ${ }^{27}$ Inequality in relation to the various dimensions of citizenship has not only been fostered by the same types of societal and economic factors which have engendered the inequality effects of the pandemic/syndemic, but also by a range of other crises, such as conflicts in Iraq and Syria (giving rise to forced migrations of many thousands of people) and the financial and later sovereign debt crises of the late 2000s and early 2010s, which have engendered policies of austerity. Of similar importance for understanding the reality of unequal citizenship are systemic and ongoing challenges such as climate change and embedded gendered and racialized structures, especially within post-colonial societies. Equality is therefore at best an aspirational principle, which ends up reinforcing the continually contested character of citizenship and the struggles of citizens and non-citizens alike for equality and full recognition within the context of the boundaries set by citizenship, operating as membership principle. Sometimes equality claims can be successful in righting historic wrongs or opening the door for excluded groups, especially in the context of constitutional litigation, but this is a relatively rare outcome. In fact, the history of citizenship can best be characterized as an ongoing "struggle to reconcile boundaries with equal treatment, collective identity with individual rights, democratic self-government with individual self-realization, and the ideal of a 'universal personhood' with the realities of a particularistic 'citizenship,' which for many is nominal at best." 28

The case for adopting a framing of constitutional citizenship for understanding the pandemic/ syndemic is strong. When we look closely, we can see that the pandemic, as perhaps the greatest public health emergency the modern world has ever known, contributes to stripping citizenship back to its fundamentals, revealing it to be not only an artefact of government (in the sense of determining the basic facts of membership and of in/exclusion) but also an omnipresent element of human community and of political organization. In that sense, the pandemic has the capacity to throw into relief the organizing moral and social principles of the idea of a bounded community, as well as challenging the political nature of those bonds and boundaries. The virus attacks core principles of human sociality by casting doubt on the desirability of touch, ${ }^{29}$ physical proximity ("social distancing"), and the possibility of certain types of group behavior, ${ }^{30}$ whilst at the same time challenging us as individuals and communities to find new and ethical modes to develop and show resilience within and across boundaries and to minimize risk for ourselves and others. All of these factors relate clearly to the constitutional foundations of different polities, and, as noted, these observations shed important light upon the pandemic's obviously disparate impacts according to well-established vectors of difference because of the clear congruence with citizenship's own conflicted relationship with equality. In that sense, any analysis of the "people and the pandemic" needs to grapple with the inevitable tensions between the symbolic role of the citizen at the heart of constitutionalism (and thus the cherished principle of equality as socio-economic and political ideal, alongside related values such as human dignity and freedom), the instrumental behavior of states and governments in relation to citizenship status and citizenship rights, and the unequal healthcare and socio-economic outcomes that flow out of the pandemic. At the same time, COVID-19 has seen the strengthening of the state across many dimensions, with extensive mobility restrictions and the use of emergency powers to enforce lockdowns. This has thrown into relief the ongoing contestation of sovereign powers between citizens themselves as political agents and states as constituted powers.

Furthermore, a framing of constitutional citizenship can also capture the dynamics of membership in times of crisis, as occurred, for example, in post-revolutionary France or in post-Civil War

\footnotetext{
${ }^{27}$ See supra note 25 , at Ch. 6 .

${ }^{28} \mathrm{Id}$. at 177.

${ }^{29}$ Isobel Sigley, It Has Touched Us All: Commentary on the Social Implications of Touch During the COVID-19 Pandemic, 2(1) Soc. SCIS. \& HuMANS. OpEN 100051 (2020).

${ }^{30}$ Nick Hopkins \& Stephen Reicher, Mass Gatherings, Health, and Well-Being: From Risk Mitigation to Health Promotion, 15(1) Soc. Issues \& POL'Y Rev. 114 (2020).
} 
United States of America, with the adoption of the Fourteenth Amendment and its extension of birthright citizenship. ${ }^{31}$ For example, enhanced citizenship status or rights have regularly been used during and after wars to reward combatants, or those whose status within society has changed as a result, for example, of labor shortages. A good example is the granting of female suffrage in many countries after the First World War during which many women had become involved in the labor market. ${ }^{32}$ The relationship between citizenship and war is complex, and goes back many centuries, right to Roman times, but has evolved in more recent times to encompass also an enhanced concern about the relationship between enemy aliens and national belonging, which casts into doubt also the allegiance of naturalized citizens. ${ }^{33}$ During the COVID-19 pandemic, tropes of war and dis-allegiance have invaded the language of many politicians, who have employed martial metaphors to suggest that combatting the virus/disease is something like a case of going to war, and who have invested the description of the virus with xenophobia, such as Donald Trump's use of "China virus", or the negative connotations invested in the naming of the "Indian variant" until the World Health Organization (WHO) retitled the variants of the virus according to the Greek alphabet in substitution for the place where they were first sequenced.

The main part of the analysis in this article highlights some of the most important areas where we can see an impact of the pandemic on aspects of citizenship as understood in its constitutional context, where there are risks that such impacts may be exacerbated by existing vulnerabilities or inequalities. There is inevitably some overlap between the different topics discussed, and the coverage is certainly not comprehensive, not least because the pandemic/syndemic remains an evolving scenario. Since the coronavirus first emerged as a threat to human health and wellbeing at the end of 2019, the COVID-19 epidemic has already passed through a number of phases. These have revealed the tensions that exist, for example, between human rights and health protection. During the initial phases of the pandemic, the primacy of health protection was characterized by strong movement restrictions, adopted in order to reduce drastically the contacts between people. In the shorter term, these could be justified on emergency grounds. In the longer term societies may need substantial regulatory and structural adjustments in order to make it possible for humans to co-exist successfully with the virus, which is likely to remain in circulation in most countries. ${ }^{34}$ Out of emergency may emerge a new experimentalism. ${ }^{35}$ Even so, the fundamental tension between individual freedoms, as well as broader social questions such as the impact on mental health, education, the economy, and the protection of the right to life and to health, especially of the most vulnerable, will persist, although how precisely this tension plays out will vary from country to country and according to the point in the cycle of the pandemic at which any given country is located. The calculus in relation to the mix of measures to be adopted depends upon scientific and medical questions as well as socio-economic and political ones. There are also profound tensions between thinking about a rights-based approach in a national context involving the partial or complete closure of borders, where the protection of the existing resident population is given precedence above other interests, and broader internationalist or global perspectives on human rights, which take into consideration, for example, the capacity of richer countries to corner supplies of drugs or vaccines, ${ }^{36}$ which are desperately needed elsewhere in the world,

\footnotetext{
${ }^{31}$ See SHAW, supra note 25.

${ }^{32}$ Michael J. Sullivan, Earned Citizenship (Oxford Univ. Press 2019).

${ }^{33}$ Daniela L. Caglioti, War and Citizenship: Enemy Aliens and National Belonging from the French Revolution to the First World War (Cambridge Univ. Press 2021).

${ }^{34}$ Nicky Phillips, The Coronavirus Is Here to Stay-Here's What That Means, 590 NATURE 382 (2021).

${ }^{35}$ Bonnie Honig, Three Models of Emergency Politics, 41 Boundary 2, 45 (2014).

${ }^{36}$ For evidence of how rich countries have cornered the supply of vaccines, see the work of Duke Global Health Innovation Center. See also Jackie Dugard, Jeff Handmaker, \& Bruce Porter, Vaccine Nationalism and Vaccine "Apartheid," OPINIO JuRIS (Feb. 18, 2021), http://opiniojuris.org/2021/02/18/mobilising-human-rights-to-address-coronavirus-vaccine-apartheid/. As of November 8, 2021, only 4.1 percent of the populations of low-income countries had received at least one dose of a coronavirus vaccine. Hannah Ritchie, Edouard Mathieu, Lucas Rodes-Guirao, Cameron Appel, Charlie Giattino, Esteban Ortiz-Ospina,
} 
or place additional weight upon the negative effects of border closures on certain groups, such as migrants or transnational families. ${ }^{37}$ These are all factors which will be built into the analysis.

The general focus in the following sections is on what might be termed the "linear effects" of COVID-19 in relation to matters of citizenship, that is to say, on the types of measures that might ordinarily be expected in a public health emergency for the purposes of saving lives or ensuring the availability of health care. For example, if public offices are closed or certain types of administrative processes are curtailed because of social distancing or other measures of infection control, then we must expect there to be impacts upon different dimensions of the citizenship principle. Both democratic and authoritarian regimes are likely to take such measures, but such measures may have differing meanings according to context. While the impacts on citizenship that emerge from public health and public order measures may be typical governmental responses to the pandemic and are not necessarily the products of the political dynamics of populism or authoritarianism, in fact such impacts are or could become problematic insofar as they may lead to major and even permanent changes to the constitutional dynamics of citizenship that have not been subject to proper scrutiny by elected representatives or consented to by the public itself. ${ }^{38}$ They therefore need to be individually assessed against standard national and international public law criteria around accountability, which themselves should have regard to questions of equality. Inevitably some measures and practices will be good, some will be bad, and some will be just what is normal. ${ }^{39}$

An underlying concern of the article is to consider how we may be able to challenge the impacts of COVID-19 on citizenship in the light of legal and constitutional standards. It is easy to see that there are a number of areas which could, in the future, be subject to legislative or judicial intervention, for example, to protect the rights or status of certain minority or vulnerable groups, in the light of principles such as equality and human dignity. Indeed, "human rights" approaches to studying the pandemic and contesting its consequences abound. ${ }^{40}$ Measures such as the Siracusa Principles on the Limitation and Derogation Provisions in the International Covenant on Civil and Political Rights, ${ }^{41}$ which have been discussed in the extensive literature assessing the COVID-19 pandemic from a human rights perspective, ${ }^{42}$ may become increasingly important for such assessments. It may be the case in the long term that durable and wide-ranging change is more likely to flow from political rather than judicial action. ${ }^{43}$ This may also be more in keeping with the political weight accorded to the oft-quoted mantra of "build back better," a phrase which stems from United Nations led work on disaster management ${ }^{44}$ but which has

Joe Hasell, Bobbie MacDonald, Diana Beltekian, Saloni Dattani \& Max Roser, Coronavirus Pandemic (COVID-19), https:// ourworldindata.org/coronavirus.

${ }^{37}$ Gerard McCann \& Féilim Ó hAdhmaill, International Human Rights and Global Welfare in the Midst of the COVID-19 Pandemic, in COVID-19 In THE Global SOUTH: IMPACTS AND ReSPONSES 29 (Pádraig Carmody et al. eds., Bristol Univ. Press 2020).

${ }^{38}$ Joelle Grogan, States of Emergency: Analysing Global Use of Emergency Powers in Response to COVID-19, 22(4) EUR. J.L. REFORM 338 (2020).

${ }^{39}$ See B. Guy Peters, Governing in a Time of Global Crises: The Good, the Bad, and the Merely Normal, 1 GLOB. PUB. POL'Y And Governance 4 (2021). See also Thomas Plümper \& Eric Neumayer, Lockdown Policies and the Dynamics of the First Wave of the Sars-CoV-2 Pandemic in Europe, J. EuR. PUB. POL'Y (2020), https://doi.org/10.1080/13501763.2020.1847170.

${ }^{40}$ Stéphanie Dagron: Going Beyond the Rhetoric: Taking Human Rights Seriously in the Post-COVID-19 New Paradigm, VERFBLOG (Mar. 27, 2021), https://verfassungsblog.de/going-beyond-the-rhetoric-taking-human-rights-seriously-in-thepost-covid-19-new-paradigm. For a methodology for studying human rights impacts, see Martin Scheinin \& Helga Molbæk-Steensig, Pandemics and Human Rights: Three Perspectives on Human Rights Assessment of Strategies Against COVID-19, (EUI LAW Working Paper, 2021), https://hdl.handle.net/1814/69576.

${ }^{41}$ International Commission of Jurists, Siracusa Principles on the Limitation and Derogation Provisions in THe International Covenant on Civil and PolitiCal Rights (July 1, 1984), https://www.icj.org/siracusa-principles-onthe-limitation-and-derogation-provisions-in-the-international-covenant-on-civil-and-political-rights/.

${ }^{42}$ See , e.g., Nina Sun, Applying Siracusa: A Call for a General Comment on Public Health Emergencies, 22 HeALTH \& Hum. RTs. 387 (2020).

${ }^{43}$ Jens O. Zinn, Conclusions: Towards a Sociology of Pandemics and Beyond, 69(4) CURRENT Socio. 603 (2021).

${ }^{44}$ Sendai Framework for Disaster Risk Reduction 2015-2030, UN OFFICE FOR DiSASTER Risk REDUCTION (2015), https://www. undrr.org/publication/sendai-framework-disaster-risk-reduction-2015-2030. For commentary in relation to COVID-19, see 
now been widely adopted as a motivating slogan at national level for the post-COVID-19 era. While this article focuses on a preliminary scoping out of how the pandemic's effects are heightened by existing inequalities and vulnerabilities, it also sets the scene for further research as the world moves through the various phases of the pandemic towards, it is hoped, better therapies, a raft of effective vaccines, an improved understanding of risky behaviors and the trade-offs involved, including for mental health, and finally a comprehensive economic recovery for all sectors of society and parts of the globe.

\section{The Impact of COVID-19 on Citizenship as Legal Status}

The effective operation of a citizenship regime is dependent not just upon constitutional norms and legislative measures but also on a literate and comprehensive bureaucratic apparatus that can ensure that life-course milestones such as births, marriages, and deaths are properly documented. These measures - especially birth registration and the provision of identity documentation, which often depends upon accurate and timely birth registration - are what give meaning to any constitutional commitment to the right to citizenship or constitutional mandate for the avoidance of statelessness. While delays in birth registration have been common in many countries during the pandemic, ${ }^{45}$ in some countries non-registration at the time of birth could translate into lifelong statelessness and inability to prove identity for the purposes of schooling, healthcare, employment, and access to other public goods. For those whose position is already precarious, or in countries where birth registration is not fully established, the impact of the pandemic is liable to amplify existing inequalities.

Although the pandemic may not generate substantial new incidences of statelessness, there is no doubt that being stateless and thus lacking the safe harbor of citizenship and the rights attached to it can be a significant aggravating factor in relation to the impact of the pandemic. This has motivated considerable efforts on the part of international public authorities and especially nongovernmental organizations focused on the elimination of statelessness to try and map in detail where there are "pinch-points" in the system, for example, because of interferences with ongoing civil registration work or disruptions to asylum and statelessness determination procedures. ${ }^{46}$ These problems may leave large numbers of people in limbo with the result that they are more likely to be deprived of rights in relation to health care, access to socio-economic support in host countries, and rights to civic and political participation. Furthermore, if societies are turning increasingly inward then there is potential for increase in discriminatory and xenophobic practices and incidences of hate and even violence against vulnerable and marginalized communities. The very "hidden" nature of statelessness can be a strong exacerbating factor in increasing exclusion and vulnerability, for example, making it easier for these groups to be missed during vaccine rollouts, whether accidentally or intentionally. ${ }^{47}$

Rhona Smith, "Building Back Better"-Obligations Behind the Soundbite, U.K. Const. L. Assoc. (Mar. 10, 2021) https://ukconstitutionallaw.org/2021/03/10/rhona-smith-building-back-better-obligations-behind-the-soundbite/; Rhona Smith, Building Back Better and Being Prepared: Lessons from COVID-19, OPINIO JURIS (Apr. 9, 2021), https://opiniojuris.org/2021/ 04/09/building-back-better-and-being-prepared-lessons-from-covid-19.

${ }^{45}$ Carla Abou Zahr, Martin Bratschi, Emily Cercone, Anushka Mangharam, Don de Savigny, Irina Dincu, Anette Bayer Forsingdal, Olga Joos, Montasser Kamal, Doris Ma Fat, Gloria Mathenge, Fatima Marinho, Raj Gautam Mitra, Jeff Montgomery, William Muhwava, Remy Mwamba, James Mwanza, Alvin Onaka, Tanja Sejersen, Maletela Touane-Nkhasi, Lynn Sferraazza, \& Philip Setel, The COVID-19 Pandemic: Effects on Civil Registration of Births and Deaths and on Availability and Utility of Vital Events Data, 111 AM. J. Pub. Health 1123 (2021).

${ }^{46}$ See Impact Report, Inst. On Statelessness and InClusion, Stateless IN A PANDEmic (2020), https://www.institutesi. org/pages/covid19_and_statelessness; Together We Can: The COVID-19 Impact on Stateless People \& a Roadmap for Change, INST. ON STATELESSNESS AND INCLUSION, (2021), https://www.institutesi.org/resources/together-we-can-report.

${ }^{47}$ See Greece's Discriminatory Vaccination Practices Render Asylum Seekers Seriously Vulnerable, EURO-MEDITERRANEAN HuMAN Rights Monitor (Mar. 22, 2021), https://reliefweb.int/report/greece/greece-s-discriminatory-vaccination-practicesrender-asylum-seekers-seriously. See also Marie Claire Van Hout, Charlotte Bigland, \& Nina Murray, Scoping the Impact of 
A further area of citizenship practice to feel the effects of COVID-19 has been that of naturalization. There have been delays to naturalization processes because of the inability to fulfil the social aspects of citizenship acquisition including handshakes or in person ceremonies, as well as problems obtaining (and indeed renewing) passports. These are all more likely to pose substantial challenges for those who find themselves at the margins or "fringes" of citizenship. ${ }^{48}$ That would include some of those who are seeking to gain citizenship by naturalization based on regular lawful residence and the fulfilment of other conditions because of their status as migrants in the host polity. So, for example, delays and obstacles may cause problems for those who risk clocking up too many days spent outside the host country because of pandemic-related travel restrictions or for young people who can no longer roll their own naturalization under the banner of those of their parents because they have passed a certain age limit.

During the pandemic, states have often been slow to rethink their approaches. Thus Ireland, which already has a notoriously slow naturalization process, stopped in person ceremonies at the inception of the pandemic. It was only in January 2021, by which time there was a backlog of 24,000 applications and 4,000 applications which were "ceremony-ready," that the national authorities replaced the ceremony with a temporary process based on a statutory declaration. ${ }^{49}$ Furthermore, the pandemic, which has changed social behaviors in so many areas, has inevitably raised questions about why handshakes may still be seen as a necessary part of a citizenship acquisition process in circumstances where handshakes have come to be seen as potential vectors of infection. Similar questions have been raised about the intersection between citizenship and veiling, given that in a number of countries the wearing of a face-covering such as the burqa and the niqab has been prohibited or regarded as a factor that could exclude the wearer from access to the host state citizenship via naturalization. ${ }^{50}$ In many countries, the wearing of a face covering as infection protection measure has become a normal practice. In some cases, the practice may extend — as has already been the case in East Asia—well beyond the parameters of the present pandemic. It might be argued that the adoption of face coverings for infection protection as standard practice should lead to questions about why other types of face coverings are seen in some countries with Muslim minorities as evidence of bad, not good, citizenship. It does not seem likely that the pandemic will generate new insights into the paradox that some face coverings are banned and others are compulsory in certain circumstances. Indeed, in the midst of the pandemic, Swiss citizens voted in a nationwide referendum in favor of a prohibition on the wearing of face coverings in public, unless this was for a health protection purpose. This is a clear step towards generating greater marginalization for the tiny minority of women of Islamic faith in that country who would choose to wear a face-covering burqa or hijab for religious reasons when in public. ${ }^{51}$

It would be incorrect to assume that all linear consequences of measures taken in relation to the pandemic as regards citizenship are in fact rights-restrictionist. In some cases, the enhancing of national and other solidarities, which many regard as central to combatting COVID-19, ${ }^{52}$ has given rise to what might be described as generous responses. Early on during the initial "first

COVID-19 on the Nexus of Statelessness and Health in Council of Europe Member States, 4 J. MigRATION AND HEALTH 100053 (2021); Talha Burki, Statelessness in the COVID-19 Pandemic, 397 THE LANCET 10284, 1529 (2021).

${ }^{48}$ Julija Sardelić, The Fringes of Citizenship (Manchester Univ. Press 2021).

${ }^{49}$ Sorcha Pollak, Temporary System to Process 4,000 Irish Citizenship Applications, THE IRIsH TIMEs (Jan. 18, 2021), https://www. irishtimes.com/news/social-affairs/temporary-system-to-process-4-000-irish-citizenship-applications-1.4461171. For details, see Press Release, Dep't J. Ir., Minister McEntee Opens Temporary Process for Granting Citizenship During COVID-19 (July 22 , 2021), https:/www.irishimmigration.ie/minister-mcentee-opens-temporary-process-for-granting-citizenship-during-covid-19/.

${ }^{50}$ See SHAw, supra note 25 , at 82-85.

${ }^{51}$ Rim-Sarah Alouane, Where Face Masks Are Required But Burqas Are Banned, ForeIGN Pol'y MAG. (Mar. 2021), https:// foreignpolicy.com/2021/03/10/switzerland-europe-burqa-ban-referendum-coronavirus-face-masks-egerkinger-komitee/.

${ }^{52}$ Jean-Paul Gagnon, Rikki Dean, Afsoun Afsahi, Emily Beausoleil \& Selen Ecran, Five Lessons for Democracy From the Covid-19 Pandemic: An International Evaluation of Democracy in Crisis, PuB. Seminar (Oct. 29, 2020), https:// publicseminar.org/essays/five-lessons-for-democracy-from-the-covid-19-pandemic/. 
wave" of the pandemic, it was widely reported in the media that Portugal was conferring temporary citizenship rights upon a group of migrants within the country. On closer inspection, ${ }^{53}$ it became apparent that the Portuguese migration authorities had issued secondary legislation protecting the situation of those who have pending applications under the Foreigners' Law or under the Asylum Law, who-after the declaration of a National State of Emergency on March 18, 2020 - could no longer be seen by the relevant authorities in person in order to review their cases. Time stood still on their applications until June 30,2020, and the measure simply secured their existing rights as lawfully resident non-citizens, thus permitting, for example, access to healthcare, to work, and to welfare benefits. Even those without legal residence status in Portugal were also given partial protection so far as concerns their right to emergency healthcare, including treatment for COVID-19 and maternal, fetal, and new born health conditions. Combined with Portugal's relatively accessible naturalization regime and newly minted ius soli principles for the second generation born in the country, ${ }^{54}$ such measures have the capacity to open out citizenship in times of crisis. We can also note the measures taken in France to accelerate the naturalization of key frontline workers who had already applied for citizenship by reducing the qualification time required for citizenship to be conferred ${ }^{55}$ and the new pathways to permanent residence for certain groups of desired workers extended to those living in Canada during the pandemic. ${ }^{56}$ This in turn provides a pathway to citizenship through naturalization, as does the extension of indefinite leave to remain in the UK for non-citizen relatives of National Health Service (NHS) workers who died of COVID-19 during the pandemic. ${ }^{57}$

It is certainly clear that the impact of travel restrictions will undoubtedly have constrained what might be termed one of the "markets" for citizenship, namely that related to birthright citizenship of convenience, or "birth tourism." This term refers to those who travel in the later stages of pregnancy to a country with unconditional ius soli with a view to giving birth in that country and thereby seeing the citizenship of that country conferred on the child.$^{58}$ While the term "birth tourism" is generally used by those who are opposed to the practice as in some way abusive of the ordinary rules of birthright acquisition in target countries such as the U.S. or Canada, the fact that this practice occurs (and indeed has been documented by researchers such as Yossi Harpaz $^{59}$ ) opens new policy options for governments in the pandemic and post-pandemic world wishing to erect tighter citizenship borders.

\footnotetext{
${ }^{53}$ Eur. Comm'N, Information for Foreign Citizens in Portugal with Pending Cases Before SEF (Apr. 27, 2020), https://ec. europa.eu/migrant-integration/news/information-for-foreign-citizens-in-portugal-with-pending-cases-before-sef. For other examples of the impact of the pandemic on migrants from outside the EU in the Member States, see EUR. Comm'N, COVID-19's Impact on Migrant Communities (last updated July 27, 2020), https://ec.europa.eu/migrant-integration/news/ covid-19s-impact-on-migrant-communities.

${ }^{54}$ Ana Rita Gil \& Nuno Piçarra, Report on Citizenship Law: Portugal, GLOBALCIT, (2020), http://hdl.handle.net/1814/ 66204. See also recent liberalization related to children, Ana Rita Gil, The 2020 Amendments to the Portuguese Nationality Act: A Big Step Further Towards Pure Ius Soli . . and Some More Inclusive Measures, GLOBALCIT (Jan. 12, 2021), https://globalcit.eu/the-2020-amendments-to-the-portuguese-nationality-act-a-big-step-further-towards-pure-iussoli-and-some-more-inclusive-measures/.

${ }^{55}$ France Facilitates Citizenship for COVID-19 Frontline Workers, GLOBALCIT (Jan. 11, 2021), https://globalcit.eu/francefacilitates-citizenship-for-covid-19-frontline-workers/. See also Bahar Makooi, France: Naturalisation des étrangers en "première ligne" contre le Covid, un effet d'annonce?, France24 (Sep. 16, 2020), https://www.france24.com/fr/20200916france-naturalisation-des-\%C3\%A9trangers-en-premi\%C3\%A8re-ligne-contre-le-covid-un-effet-d-annonce.

${ }^{56}$ Shelby Thevenot, Canada's New Essential Worker Stream Reaches Intake Cap, CIC News (July 16, 2021), https://www. cicnews.com/2021/07/canadas-new-essential-worker-stream-reaches-intake-cap-0718646.html\#gs.ebj44e.

${ }^{57}$ Guidance from UK Home OfFICE \& VISAS AND IMMIGR., Coronavirus (COVID-19): Bereavement Scheme for Family Members of NHS and Health and Social Care Workers, GOV.UK, (Jun. 16, 2021), https://www.gov.uk/guidance/ coronavirus-covid-19-bereavement-scheme-for-family-members-of-nhs-and-health-and-social-care-workers.

${ }^{58}$ Graeme Wood, Record-setting Year for Birth Tourism in B.C. Prior to Pandemic, Bus. VAncouver (Aug. 27, 2020), https://biv.com/article/2020/08/record-setting-year-birth-tourism-bc-prior-pandemic.

${ }^{59}$ Yossi Harpaz, Mexico: Strategic Birth as Elite Investment, Citizenship 2.0: Dual Nationality as a Global Asset 67 (Yossi Harpaz ed., Princeton Univ. Press 2019).
} 
All of these reflections raise a more general question about whether the pandemic could lead to a substantial reshaping of patterns of citizenship acquisition and loss and the increasingly transnational character of citizenship for many people. Dual and even multiple citizenship arises for a variety of reasons including by birth, via various forms of ordinary residence-based naturalization and registration for migrants and their families, and via facilitated naturalization for certain privileged groups of non-residents. State tolerance of dual citizenship has increased dramatically since the Second World War, and gradual liberalization continues in some parts of the world ${ }^{60}$ Peter Spiro does not see any serious likelihood of the trend towards wider acceptance of dual citizenship being reversed in the post-pandemic world, even though much of the normal churn of immigration-related mobility did grind to a halt as a result of travel restrictions at least in the earlier phases of the pandemic. However, he acknowledges that in relation to one segment of the dual citizenship universe, that is, the conferral of citizenship upon non-residents in return for an investment, the impact of the pandemic on mobility is likely to have at least a short-term effect, as these types of "luxury good" citizenships no longer confer travel privileges in the same way in a world that has been, at least temporarily, less mobile even for the most privileged groups. ${ }^{61}$ Yet, neither he nor Kristin Surak ${ }^{62}$ see that market as likely to be substantially impinged upon in the longer term. Surak suggests adjustments so that residence by investment rather than non-resident citizenship, with its connotations of a safe haven, becomes potentially the most desirable good for the superwealthy to purchase. Meanwhile, Jelena Džankić suggests that thus far the impacts of the pandemic upon states may have been underestimated and a different type of cost-benefit analysis may flow if states become more protective of their borders and healthcare systems. ${ }^{63}$ Yet, by definition, investor residents and citizens are supposed to be net payers, and under conditions where states have lost other types of conventional tourism income-for example, in the Caribbean-investment citizenship may seem doubly desirable. That speaks to the supply side of the equation. Judging the demand side is a tricky task, not least because this is a group that remains hard to research. ${ }^{64}$

These possible effects in relation to acquisition and loss of citizenship, however, stand at the opposite end of the spectrum to where the primary concern of this article lies, namely with the potentially exclusionary effects of the pandemic on those for whom even a single effective citizenship is a chimera in the distance. For the latter groups, it is clear that delays in birthright registration and restrictions on immigration during the pandemic have the potential to exacerbate existing inequalities in relation to access to the public goods associated with citizenship as membership. It is to the wider framing of that latter point on immigration, namely pandemic (im) mobilities, that we now turn.

\section{D. (Im)mobility in a Pandemic}

The pandemic has given rise to a dramatic reduction in mobility, according to data available from mobile phone companies and transportation authorities. ${ }^{65}$ Far-reaching governmental measures

\footnotetext{
${ }^{60}$ See Peter Spiro, Multiple Citizenship, in The Oxford Handbook of Citizenship 621, 631-34 (Ayelet Shachar et al. ed., Oxford Univ. Press 2017).

${ }^{61}$ Peter Spiro, COVID-19 and the Future of Dual Citizenship, GLOBALCIT (May 15, 2020), https://globalcit.eu/covid-19and-the-future-of-dual-citizenship/.

${ }^{62}$ Kristin Surak, How COVID-19 Will Transform the Market in Investment Migration, GLOBALCIT (June 5, 2020), https:// globalcit.eu/how-covid-19-will-transform-the-market-in-investment-migration/.

${ }^{63}$ See Jelena Džankić, Will the Global Market for Investor Citizenship Survive COVID-19?, GLOBALCIT (May 21, 2020), https://globalcit.eu/will-the-global-market-for-investor-citizenship-survive-covid-19/.

${ }^{64}$ Kristin Surak, Millionaire Mobility and the Sale of Citizenship, 47 J. Ethnic \& Migration Stud. 166 (2020). See also Jelena Džankić, The Global Market for Investor Citizenship (Palgrave, 2019).

${ }^{65}$ Nouvellet P, Bhatia S, Cori A, Ainslie KEC, Baguelin M, Bhatt S, Boonyasiri A, Brazeau NF, Cattarino L, Cooper LV, Coupland H, Cucunuba ZM, Cuomo-Dannenburg G, Dighe A, Djaafara BA, Dorigatti I, Eales OD, van Elsland SL, Nascimento FF, FitzJohn RG, Gaythorpe KAM, Geidelberg L, Green WD, Hamlet A, Hauck K, Hinsley W, Imai N, Jeffrey B, Knock E, Laydon DJ, Lees JA, Mangal T, Mellan TA, Nedjati-Gilani G, Parag KV, Pons-Salort M, Ragonnet-Cronin M, Riley S, Unwin HJT, Verity R, Vollmer
} 
were imposed first in China and then around the world as the virus itself traveled to every corner of the globe. Under this heading, we could subsume not just travel restrictions within and across states ${ }^{66}$ but also stay-at-home mandates that have reduced the numbers of contacts at a population level and correlated with lower transmission rates for COVID-19 infections. ${ }^{67}$ Stay-at-home mandates, which can be thought of as "everyday mobility" restrictions, are, however, best examined under the category of intrusions into the private lives of citizens. These are the focus of the following section. This section looks mainly at the management of borders, especially state borders, in the context of the pandemic, and thus the impact on travel. This is a place where engagement with the boundaries of citizenship is especially clear.

The most visible aspect of the management of borders during the course of the pandemic has been the imposition of widespread travel bans and restrictions, including new bureaucracy around traveling such as tests, passenger locator forms, and quarantine/isolation requirements. Yet at the same time as travel restrictions have reduced mobility at the aggregate scale, so also various other forms of involuntary or less-than-wholly-voluntary mobility have continued throughout the period, even if at reduced levels. ${ }^{68}$ The involuntary mobile are not all travelers in any conventional sense. The category includes homeless persons, who have no home to stay in, ${ }^{69}$ and migrant workers in countries like India, forced to leave the cities to return to the countryside. ${ }^{70}$ Across the world armed conflicts - which result in displaced civilian populations-have continued or restarted, feeding the volume of involuntary mobile persons. ${ }^{71}$

Throughout the period, some voluntary mobility has continued, especially amongst groups which have privileged access to the extra resources, such as testing and vaccination, which are now generally required for travel. Elite athletes, for example, have not been subject to the same travel restrictions as others because they are frequently tested and so are not always required to quarantine in the same way as ordinary travelers ${ }^{72}$ or have had privileged access to certain countries, as in the case of tennis players traveling to Australia for the Australian Open tournament in $2021 .^{73}$ The capacity to travel and even to travel for vaccination purposes ${ }^{74}$ has become a new kind of luxury good, like citizenship

MAC, Volz E, Walker PGT, Walters CE, Wang H, Watson OJ, Whittaker C, Whittles LK, Xi X, Ferguson NM, Donnelly CA., Reduction in Mobility and COVID-19 Transmission, 12 NATURE COMMC'Ns 1090 (2021).

${ }^{66}$ For data on travel restrictions, see Lorenzo Piccoli, Jelena Dzankic, \& Didier Ruedin, Citizenship, Migration and Mobility in a Pandemic (CMMP): A Global Dataset of COVID-19 Restrictions on Human Movement, 16(3) PLOS ONE e0248066 (2021), https://www.ncbi.nlm.nih.gov/pmc/articles/PMC7943018/.

${ }^{67}$ Hakan Yilmazkuday, Stay-at-home Works to Fight Against COVID-19: International Evidence from Google Mobility Data, 31(1-4) J. Hum. BeHav. Soc. Env't 210 (2021).

${ }^{68}$ Leiza Brumat \& Victoria Finn, Mobility and Citizenship During Pandemics: The Multilevel Political Responses in South America, 14 Partecipazione e Conflitto 321 (2021); Victoria Finn \& Mari-Liis Jakobson, Mobility During Pandemics: Moving Borders and Citizenship into Uncharted Territories, 9(5-6) COSMOS + TAXIS 109 (2021), https:// cosmosandtaxis.files.wordpress.com/2021/05/finn_jakobson_ct_vol9_iss_5_6.pdf.

${ }^{69}$ Vanessa M. Fenley, Everyday Citizenship and COVID-19: "Staying at Home" While Homeless, 43(2) AdMIN. THEORY \& PRAXIS 245 (2021).

${ }^{70}$ Amit Prakash, Shadow of the Pandemic and the Beleaguered Liberal-Democratic Script in India, 20(2) INDIA REv. 104 (2021).

${ }^{71}$ See data collected in COVID-19 Disorder Tracker, ACLED, https://acleddata.com/analysis/covid-19-disorder-tracker/. See also Marius Mehri \& Paul W. Thurner, The Effect of the Covid-19 Pandemic on Global Armed Conflict: Early Evidence, 19(2) Pol. STUD. REV. 286 (2021).

${ }^{72}$ See , e.g., Guidance from UK DeP’t Digital, Culture, Media \& SPORT, Guidance on Coronavirus (COVID-19) Measures for Elite Sport, GOV.UK (Oct. 8, 2021), https://www.gov.uk/government/publications/guidance-on-coronavirus-covid-19measures-for-elite-sport.

${ }^{73}$ The fact that tennis players and their entourages were not subject to the restrictions imposed by the cap imposed by the Australian government has provoked strong reactions when more than 1,000 persons were allowed entry to Australia-subject to tests and quarantine restrictions that were privately organized but supervised by the government-for the Australian Open tennis tournament. See Sophie Williams, Tennis Stars'Arrival Angers Stranded Australians, BBC News (Jan. 16, 2021), https:// www.bbc.com/news/world-australia-55683035.

${ }^{74}$ Jemma Carr, Wealthy Members of $£ 25,000$-a-year Knightsbridge-based Travel Concierge Service Who Are Aged Over 65 Are Being Flown to the United Arab Emirates and India on Private Jets to Receive the Covid Jab, DAILY MAIL (Jan. 14, 2021), https:// www.dailymail.co.uk/news/article-9147557/Travel-concierge-service-charging-members-40-000-private-Covid-jab.html. 
by investment. ${ }^{75}$ The rise in costs has substantially burdened migrant workers and those with transnational families, for whom travel is part of family life, not a luxury, a recreation, or a lucrative business. $^{76}$ This could be described as the decline of the everyday global citizen. ${ }^{77}$

New norms are emerging in relation to immigration, blurring the distinction between voluntary and involuntary mobility. ${ }^{78}$ There are still many migrant workers crossing borders in many parts of the world, ${ }^{79}$ either returning home because the jobs they performed no longer exist, or traveling to work because various countries require temporary migrants to do certain types of jobs, for example, in the agricultural, agri-industrial, and food processing domain. Countries can justify ostensibly risky mobility on grounds of food security ${ }^{80}$ or even consumer preference. ${ }^{81}$ The churn of migration may have reduced, but it has not ended, ${ }^{82}$ and this has consequences for public policy. ${ }^{83}$ For these purposes, new concepts of essential and inessential travel have been developed, and the interface between these concepts and economic power and affluence-both at the societal and individual levels - has given rise to new sites of inequality and sources of vulnerability, for example, in relation to access to healthcare and vaccines. The application of these concepts needs to be understood in context: As Audrey Macklin shows, in the context of Canada it is the context of being a settler colonial "country of immigration" that matters as regards whether travel by noncitizen family members of residents or seasonal workers is deemed essential or inessential. ${ }^{84}$

A connection is often drawn between borders and citizenship or nationality, as the border is commonly the place where we must prove our identity or our belongingness to a given community. However, borders are now complex and multi-facetted structures, and understanding them must go beyond the conventional binary of "open" or "closed". As Ayelet Shachar argues, ${ }^{85}$ we need to take a nuanced perspective on the nature and effects of borders, not all of which are located at the edges of countries, but may also be found internally. Actions taken by states to restrict non-citizen entry and to encourage non-resident citizen return along with-at the micro levelthe changes in personal lifestyle and migration calculations made by many migrants all seem to point to a degree of de-globalization occurring, as well as a reversal of trends in immigration and emigration that may not be reversed for some years or even decades. The picture, however, is complex, and other factors such as the direction of travel, in or out, the origin and destination of the traveler, and whether the restriction is on internal movement or movement across state borders will also matter. ${ }^{86}$ Furthermore, the evolution of green, amber, and red lists of countries, as in the UK, has often been

\footnotetext{
${ }^{75}$ See Džankić, supra note 63.

${ }^{76}$ Andrea Preziosi, When States Steal Christmas: The Citizens' Right to Return to the Country of Citizenship in Time of Pandemic, STRASBourg ObSERVERS (Jan. 7, 2021), https://strasbourgobservers.com/2021/01/07/when-states-stealchristmas-the-citizens-right-to-return-to-the-country-of-citizenship-in-time-of-pandemic/.

${ }^{77}$ Atefeh Ramsari, The Rise of the COVID-19 Pandemic and the Decline of Global Citizenship, in COVID-19 VOLUME I: Global Pandemic, Societal Responses, Ideological Solutions 94 (J. Michael Ryan ed., 2021).

${ }^{78}$ Mariña Fernández-Reino, Madeleine Sumption \& Carlos Vargas-Silva, From Low-skilled to Key Workers: The Implications of Emergencies for Immigration Policy, 36 OXford ReV. ECON. POL'y Supp. S382-S396 (2020).

${ }^{79}$ Diego Acosta \& Leiza Brumat, Political and Legal Responses to Human Mobility in South America in the Context of the Covid-19 Crisis. More Fuel for the Fire?, 2 Frontiers Hum. DynAmics 592196 (2020).

${ }^{80}$ Michael D. Smith \& Dennis Wesselbaum, COVID-19, Food Insecurity, and Migration, 150 J. NuTRITION 2855 (2020).

${ }^{81}$ Rob Schmitz, Germany Struggles to Fill Its Farm Labor Shortage After Closing Its Borders, NAT'L PuB. RADIO (May 20 , 2020), https://www.npr.org/2020/05/20/858564234/germany-is-struggling-to-fill-its-farm-labor-shortage-after-closing-itsborders? $\mathrm{t}=1610983125442$.

${ }^{82}$ Migration in the Time of COVID-19: Comparative Law and Policy ResPonses (Jaya Ramji-Nogales \& Iris Goldner Lang, eds. 2021).

${ }^{83}$ Refugees and Migrants in Times of COVID-19: Mapping Trends of Public Health and Migration Policies and PraCtiCES, WHO (Jun. 17, 2021), https://www.who.int/publications/i/item/9789240028906.

${ }^{84}$ Audrey Macklin, (In)Essential Bordering: Canada, COVID, and Mobility, 2 FronTIERS Hum. DynAmics 609694 (2020)

${ }^{85}$ Ayelet Shachar, Beyond Open and Closed Borders: The Grand Transformation of Citizenship, 11 JURISPRUDENCE 1 (2020).

${ }^{86}$ Jouni Häkli, COVID-19 Certificates as a New Form of Mobility Control, 12(2) EUR. J. Risk RegUl. 362 (2021); Jaclyn L. Neo \& Darius Lee, Borders and Entry Controls in Asia, in Covid-19 In AsIA: LAW AND Policy ConTEXTs (Victor V. Ramraj ed., Oxford Univ. Press 2021).
} 
determined as much by political considerations as it has by reference to epidemiological or scientific data. Travel restrictions have even, as the pandemic has moved into its later stages, been conditioned by the availability of vaccines, which the richer countries themselves largely control. This profoundly undermines the position of those with the citizenship of, or family or business connections with, those countries that are deemed to pose greater risks. It highlights familiar neo-colonial patterns organized around the racialization of risk and disease. ${ }^{87}$

While the implications of the mobility and travel restrictions that have been imposed stretch beyond the issue of citizenship, they are none the less frequently conditioned by the contours of formal membership. For example, holding a national passport or having permanent resident status is necessary for entry or for residence in a particular part of a country. ${ }^{88}$ COVID-19 related emergency measures have impacted upon different groups of citizens in different ways. Amongst the groups of citizens who were located outside their home country at the point when the restrictions were imposed there will be those whose absence from the home country is temporary and those whose absence is permanent, along with many shades between the two. These groups will also include those who hold single citizenship (perhaps in combination with a residence permit in the host country or a special status like India's Overseas Citizenship to allow return to the country of origin where citizenship has been lost) and those who are dual or multiple citizens. Diasporas have come to the forefront of policymaking during the pandemic, notably as a result of the dilemma as to whether to persuade them to return "home" or to "stay put" and thus to continue producing the remittances that may contribute to offsetting the economic impact of the pandemic and that can move digitally without any requirement of physical movement in our financially interconnected world. A minority of countries have imposed restrictions on their "own" nationals, in apparent violation of Article 12(4) of the International Covenant on Civil and Political Rights, which provides for the right for everyone to be able to return to their "own country." 89 This raises doubts about the caps placed by New Zealand and Australia on returning citizens on the grounds of limited quarantine capacity, ${ }^{90}$ about the steps taken by Australia to criminalize citizens returning from India at certain points, although these have been upheld in the courts, ${ }^{91}$ and about India's withdrawal of the visa privileges associated with the status of overseas citizen or person of Indian origin. ${ }^{92}$ There are a number of countries which have prohibited citizens from leaving without permission during the pandemic. ${ }^{93}$

\footnotetext{
${ }^{87}$ Marcos S. Scauso, Garrett FitzGerald, Arlene Tickner, Navnita Chadha Behera, Chengxin Pan, Chih Yu Shih, \& Kosuke Shimizu, COVID-19, Democracies, and (De)Colonialities, 7 Democratic Theory 82 (2020); Matiangai Sirleaf, Entry Denied: COVID-19, Race, Migration, and Global Health, in Frontiers Hum. Dynamics (2020).

${ }^{88}$ Leaving aside the issue of mobility within states and the implications of often quite draconian "stay at home" orders or bans on public transport with the implications that these have for personal liberty and other human rights. See source cited infra note 148 for a discussion of India. For a case study, see Timothy Affonso, The Legality and Enforceability of "Stay-athome" Orders: The Appropriate Response to Covid-19 by Trinidad and Tobago, 46 Commonwealth L. Bull. 183 (2020).

${ }^{89}$ For discussion, see Rutsel Martha \& Stephen Bailey, The Right to Enter His or Her Own Country, EJIL:TALK!, (Jun. 23, 2020), https://www.ejiltalk.org/the-right-to-enter-his-or-her-own-country/; Jaclyn L. Neo \& Darius Lee, Borders and Entry Controls in Asia, in Covid-19 IN Asia: LAw AND Policy ConTexts (Victor V. Ramraj ed., Oxford Univ. Press 2021).

${ }^{90}$ For a comprehensive review of the Australian restrictions as of September 2021, see Leanne Weber, Membership Without Mobility: The Counterfactual as Fact, GLOBALCIT (Sept. 2, 2021), https://globalcit.eu/mobility-without-membership-do-weneed-special-passports-for-vulnerable-groups/10/.

${ }^{91}$ Liz Hicks, Australia and the Right of Repatriation: Why Have "Stranded" Australian Citizens Brought a Complaint Against Their Government in the United Nations?, VERFBLOG, (Apr. 12, 2021), https://verfassungsblog.de/australia-and-the-right-ofrepatriation/; Sangeetha Pillai, Is Australia's India Travel Ban Legal? A Citizenship Law Expert Explains, KALDOR CENTRE BlOG (May 5, 2021), https://www.kaldorcentre.unsw.edu.au/publication/australia\%E2\%80\%99s-india-travel-banlegal-citizenship-law-expert-explains; Sangeetha Pillai, Australian Citizenship: Lessons from the India Travel Ban, LSJ OnLINE (May 28, 2021), https://lsj.com.au/articles/australian-citizenship-lessons-from-the-india-travel-ban/.

${ }^{92}$ Government Relaxes Visa Restrictions, THE HINDU, (Oct. 22, 2020), https://www.thehindu.com/news/national/indiarelaxes-visa-restrictions/article32916564.ece.

${ }^{93}$ This is not so uncommon: For example, between March 29 and May 17, 2021, ostensibly in order to prevent UK residents from taking foreign holidays, there was a general ban on leaving the UK except for certain reasons-as these were limited to work, volunteering, education, medical needs, and to attend weddings or funerals, they were of little assistance to transnational
} 
If the effects of various measures taken to contain the pandemic or its socio-economic dimensions restrict citizenship privileges and rights, then this will once again impact more significantly upon those with weaker economic status, as well as those with the citizenships of poorer countries or of countries lacking the infrastructure or will to act protectively. Commentators have noted that some rich countries were quick to mount repatriation efforts, expending consular, financial, and medical resources in order to protect "their" nationals ${ }^{94}$ and to issue come home calls. ${ }^{95}$ This has resulted in difficulties for multiple citizenship families. For example, China was reluctant to allow its citizens married to citizens from other countries and with non-citizen children to leave China with their families and some countries - such as Canada initially, but it eventually changed its policy-have been reluctant to allow non-citizen spouses to enter, even with their citizen children for whom they are the primary caregivers. However, the majority of countries have instituted exceptions in relation to entry for permanent residents. ${ }^{96}$

Many of these scenarios raise questions of diplomacy, as well as, classic international law dilemmas about the character of nationality as a link between the state and the individual and its recognition under principles of international diplomacy via the controversial Nottebohm "genuine link" principle. ${ }^{97}$ Frédéric Mégret ${ }^{98}$ describes the general tenor of national policies as involving a romantic emphasis on nationality, and draws on Michel Foucault to suggest that this involves states taking governing to be "a 'pastoral' mission-including in its sacrificial function of deciding who to "let die" - - where the shepherd is seen to rally its "stranded" flock. He also suggests that this represents an archaic approach to the concept of "protection," insofar as it is clear that most of the "shielding" that closing borders provided has been illusory rather than real, except in cases like New Zealand, which benefits from geographical advantages of insularity and remoteness.

Of particular interest are the restrictions on mobility imposed by states in the context of the European Union, especially because of the implications of these for the supranational status of European citizenship. These restrictions need to be viewed in the context of EU law, which has both a framework providing the free movement of persons (including the free movement of labor) and non-discrimination on grounds of nationality as core principles and a framework for the elimination of internal border controls and the creation of a common approach to the management of the external border as part of the Schengen zone. This zone gathers together most EU Member States and a number of third countries. Open borders, along with the protection

families - set out in Health Protection Regulations adopted specifically for COVID-19 controls. See also, on the Australian case, which has persisted much longer, Regina Jefferies \& Jane McAdam, Who's Being Allowed to Leave Australia During COVID? FOI Data Show It Is Murky and Arbitrary, UNSW L. (Jul. 5, 2021), https://www.kaldorcentre.unsw.edu.au/ publication/who\%E2\%80\%99s-being-allowed-leave-australia-during-covid-foi-data-show-it-murky-and-arbitrary.

${ }^{94}$ Frédéric Mégret, COVID-19 Symposium: Returning "Home"-Nationalist International Law in the Time of the Coronavirus, OPINIO JURIS (Mar. 30, 2020), http://opiniojuris.org/2020/03/30/covid-19-symposium-returning-homenationalist-international-law-in-the-time-of-the-coronavirus/. For a detailed appraisal of the measures taken by Cyprus, including repatriation, see Angeliki Konstantinidou \& Daniela Vintila, Policy Measures for the Diaspora During the COVID-19 Crisis: The Case of Cyprus, 1 Hellenic Assoc. Pol. SCI. 13 (2020).

${ }^{95}$ See Angeliki Konstantinidou \& Daniela Vintila, Policy Measures for the Diaspora During the COVID-19 Crisis: The Case of Cyprus, 1 Hellenic Assoc. Pol. SCI. 13 (2020). See also the case of Singapore: COVID-19: 85 Singapore Citizens, Residents Repatriated from Saudi Arabia, CAN (Apr. 24, 2020), https://www.channelnewsasia.com/news/singapore/saudi-arabia-covid19-singapore-residents-repatriated-12672870; Chun Han Wong, Governments Ask Their Citizens to Come Home as Coronavirus Cases Spread, WALL ST. J. (Mar. 18, 2020), https://www.wsj.com/articles/governments-ask-their-citizens-tocome-home-as-coronavirus-cases-spread-11584528789.

${ }^{96}$ See Piccoli, supra note 66.

${ }^{97}$ Liechtenstein v. Guatemala (Nottebohm) 1955 I.C.J. 1 (Apr. 6).

${ }^{98}$ Frédéric Mégret, COVID-19 Symposium: Returning "Home"-Nationalist International Law in the Time of the Coronavirus, OPINIO JURIS (Mar. 30, 2020), http://opiniojuris.org/2020/03/30/covid-19-symposium-returning-homenationalist-international-law-in-the-time-of-the-coronavirus/. See also other works by Mégret emphasizing the importance of a re-orientation towards thinking about the state of nationality: Frédéric Mégret, Homeward Bound? Global Mobility and the Role of the State of Nationality During the Pandemic, 114 AJIL Unbound 322 (2020); Frédéric Mégret, The Changing Face of Sovereign Protection in International Law, 21(2) MeLbourne J. INT'L L. 1 (2021). 
provided by principles of free movement and non-discrimination for the legal rights of EU citizens, have substantial symbolic power and pull for the EU. ${ }^{99}$

Faced with a huge diversity of responses by the Member States, the European institutions' response to the challenge posed by closed borders within the EU, especially during the first wave of the pandemic in March to June 2020, was marked by extensive recourse to "soft law," rather than vain efforts at legal enforcement to force collective action. The aim was to persuade the Member States to keep certain sorts of movement going throughout and then gradually to loosen restrictions on mobility within the $\mathrm{EU}^{100}$ and also at the external borders. ${ }^{101}$ Iris Goldner Lang describes this as an application of the precautionary principle in the context of public health derogations that are undoubtedly permitted under the existing free movement principles. ${ }^{102}$

Closer-and critical-attention ${ }^{103}$ has been paid to the creation of an EU Digital COVID certificate, ${ }^{104}$ related to proof of COVID-19 vaccination, test, or recovery, to allow not just free movement between states and passage across the external frontiers of the $\mathrm{EU}^{105}$ but also-at the discretion of Member States - access to facilities within states, such as museums, leisure facilities, concerts, and even shops. As regards issues of mobility across borders, this development is part of a wider global movement towards the adoption of vaccine passports. It builds upon some of the existing digital trust schemes to promote easy mobility for global elites through airports and across

\footnotetext{
${ }^{99}$ Daniel Thym \& Jonas Bornemann, Schengen and Free Movement Law During the First Phase of the Covid-19 Pandemic: Of Symbolism, Law and Politics, 5(3) EUR. PAPERS 1143 (2020).

${ }^{100}$ Commission Communication Guidelines Concerning the Exercise of the Free Movement of Workers During COVID-19 Outbreak, 2020/C 102 I/03, 2020 O.J. C 1021 (Mar. 30, 2020), https://eur-lex.europa.eu/legal-content/EN/TXT/?uri=CELEX: 52020XC0330(03); Commission Communication Guidelines on Seasonal Workers in the EU in the Context of the COVID-19 Outbreak, 2020/C 235 I/1, 2020 O.J. C 2351 (Jul. 17, 2020), https://eur-lex.europa.eu/legal-content/EN/TXT/?uri=CELEX: 52020XC0717(04); Council Recommendation (EU) 2020/1475 on a Coordinated Approach to the Restriction of Free Movement in Response to the COVID-19 Pandemic, 2020 O.J. (L 337/3), (Oct. 14, 2020), http://data.europa.eu/eli/reco/ 2020/1475/oj; Commission Communication Towards a Phased and Coordinated Approach for Restoring Freedom of Movement and Lifting Internal Border Controls-COVID-19, 2020/C 169/3 C/2020/3250, 2020 O.J. C 169 (May 15, 2020) https://eur-lex.europa.eu/legal-content/EN/TXT/?uri=uriserv:OJ.C_.2020.169.01.0030.01.ENG.

${ }^{101}$ Commission Communication COVID-19 Guidance on the Implementation of the Temporary Restriction on Non-essential Travel to the EU, on the Facilitation of Transit Arrangements for the Repatriation of EU Citizens, and on the Effects on Visa Policy, 2020/C 102 I/2 C/2020/2050 2020 O.J. C 1021, (Mar. 30, 2020), https://eur-lex.europa.eu/legal-content/EN/TXT/? uri=CELEX:52020XC0330(02); Council Recommendation (EU) 2020/912 on the Temporary Restriction on Non-essential Travel into the EU and the Possible Lifting of Such Restriction, ST/9208/2020/INIT 2020 O.J. (L 208I/1) (Jul. 1, 2020) http://data.europa.eu/eli/reco/2020/912/oj; Commission Communication on the Third Assessment of the Application of the Temporary Restriction on Non-essential Travel to the EU, COM (2020) 399 final (Jun. 11, 2020), https://eur-lex. europa.eu/legal-content/EN/TXT/?uri=CELEX:52020DC0399.

${ }^{102}$ See Iris Goldner Lang, "Laws of Fear" in the EU: The Precautionary Principle and Public Health Restrictions to Free Movement of Persons in the Time of COVID-19, EUR. J. RISK REGUL. (2021), https://www.cambridge.org/core/journals/european-journal-of-riskregulation/article/laws-of-fear-in-the-eu-the-precautionary-principle-and-public-health-restrictions-to-free-movementof-persons-in-the-time-of-covid19/56741AF86D63D0465EC1AA364CA136CB. See also Sophie Robin-Olivier, Free Movement of Workers in the Light of the COVID-19 Sanitary Crisis: From Restrictive Selection to Selective Mobility, 5 EuR. PAPERS 613 (2020).

${ }^{103}$ See Alberto Alemanno \& Luiza Bialasiewicz, Certifying Health: The Unequal Legal Geographies of COVID-19 Certificates, 12 Eur. J. Risk Regul. 273 (2021). This paper is the introduction to an extensive special issue on the topic.

${ }^{104}$ For a basic primer, see EUR. COMM'N, EU Digital COVID Certificate, https://ec.europa.eu/info/live-work-travel-eu/ coronavirus-response/safe-covid-19-vaccines-europeans/eu-digital-covid-certificate_en.

${ }^{105} \mathrm{EP}$ and Council Regulation (EU) 2021/953 on a Framework for the Issuance, Verification and Acceptance of Interoperable COVID-19 Vaccination, Test and Recovery Certificates (EU Digital COVID Certificate) to Facilitate Free Movement During the COVID-19 Pandemic, PE/25/2021/REV/1 2021 O.J. (L 211), (Jun. 15, 2021), http://data.europa.eu/ eli/reg/2021/953/oj; EP and Council Regulation (EU) 2021/954 on a Framework for the Issuance, Verification and Acceptance of Interoperable COVID-19 Vaccination, Test and Recovery Certificates (EU Digital COVID Certificate) with Regard to Third-country Nationals Legally Staying or Residing in the Territories of Member States During the COVID-19 Pandemic, 24-28, PE/26/2021/REV/1 2021 O.J. (L 211), (Jun. 15, 2021), http://data.europa.eu/eli/reg/2021/954/oj.
} 
frontiers. The main challenges for regulators include data protection issues, ${ }^{106}$ the regulation of novel technologies, ${ }^{107}$ fairness and equity questions ${ }^{108}$ stemming from uneven vaccine distribution across the globe and even within countries that apply age and priority focuses or that de jure or de facto exclude marginalized populations. ${ }^{109}$ There are also issues which arise for those who are unable to take up vaccination opportunities because of underlying health conditions. Finally, there is the overriding question of how far it is permitted, in the interests of combatting a public health emergency, for regulators to intrude in the private life of citizens, residents, and visitors. Leaving behind the question of pandemic (im)mobilities, it is to this issue that we now turn.

\section{E. Intrusions of COVID-19 into the Sphere of Private Life}

Rights to privacy and respect for private and family life are not, as such, rights of citizenship. Such rights are very often also extended, although not always to the same extent, to non-citizens accessing or residing in a country. There are therefore blurred boundaries to be drawn between constitutional rights, fundamental rights, human rights, and rights of citizenship. Nonetheless, it remains important to discuss the rights dimension of COVID-19's impact as a dimension of membership, as the contestation of rights is not only politically salient but can also give rise to potential legal claims for citizens and others that reconstruct both the underpinning values of universal personhood and the concept of citizenship as bounded membership. ${ }^{110}$

Trying to combat the spread of a virus where there is asymptomatic and pre-symptomatic spread unsurprisingly entails substantial incursions into personal freedoms, going beyond the strict stay-at-home orders and travel bans that were common in the lockdowns during the socalled first wave of infections both in democracies and authoritarian states. ${ }^{111}$ Controlling the virus has not only taken the form of isolation measures ${ }^{112}$ or access restrictions, for example, care home or hospital visit bans, but also surveillance measures such as apps on mobile phones which have become widespread as voluntary supplements to contact-tracing efforts in many countries, but which residents, and especially arriving travelers, are required to use in some countries. Such apps have profound implications for privacy if they are not set up in such a way as to remain anonymous and unless they are designed with ethical usage in mind to avoid, for example, subtle coercive pressures. ${ }^{113}$ Furthermore, as remote learning became increasingly normalized, the use of apps such as proctoring software for remote examinations has also become more common. ${ }^{114}$

\footnotetext{
${ }^{106}$ Oskar Josef Gstrein, The EU Digital COVID Certificate: A Preliminary Data Protection Impact Assessment, 12 EUR. J. RISK REGUL. 370 (2021).

${ }^{107}$ Sara Helen Wilford, Neil McBride, Laurence Brooks, Damian Eke, Simisola Akintoye, Adebowale Owoseni, Tonii Leach, Catherine Flick, Malcolm Fisk \& Martin Stacey, The Digital Network of Networks: Regulatory Risk and Policy Challenges of Vaccine Passports, 12 EUR. J. RIsK REGUL. 393 (2021).

${ }^{108}$ Sarah Ganty, The Veil of the COVID-19 Vaccination Certificates: Ignorance of Poverty, Injustice Towards the Poor, 12 EUR. J. RISK REGUL. 343 (2021).

${ }^{109}$ Sarah Haque \& Laura Margottini, Red Tape Keeping Covid Vaccine Out of Reach for Nearly 4 M Undocumented Migrants Across Europe, Bureau of Investigative Journalism (Sept. 1, 2021), https://www.thebureauinvestigates.com/stories/202109-01/red-tape-keeping-covid-vaccine-out-of-reach-for-nearly-4m-undocumented-migrants-across-europe.

${ }^{110}$ See SHAw, supra note 25, at Ch. 5.

${ }^{111}$ Alessandra Spadaro, COVID-19: Testing the Limits of Human Rights, 11(2) EUR. J. Risk Regul. 317 (2020).

${ }^{112}$ The French conseil constitutionnel decided that compulsory isolation on a generalized basis is contrary to the French constitution in its decision of Aug. 5, 2021. Conseil constitutionnel [CC] [Constitutional Court] decision No. 2021-824D Aug. 5, 2021, https://www.conseil-constitutionnel.fr/decision/2021/2021824DC.htm. See also Conseil Constitutionnel, Press release, https://www.conseil-constitutionnel.fr/actualites/communique/decision-n-2021-824-dc-du-5-aout-2021-communiquede-presse.

${ }^{113}$ Renate Klar \& Dirk Lanzerath, The Ethics of COVID-19 Tracking Apps-Challenges and Voluntariness, 16(3-4) RsCH. ETHICs 1 (2020), https://doi.org/10.1177/1747016120943622.

${ }^{114}$ Simon Coghlan, Tim Miller, \& Jeannie Paterson, Good Proctor or "Big Brother"? AI Ethics and Online Exam Supervision Technologies, ARXIV, (Nov. 15, 2020), https://arxiv.org/abs/2011.07647.
} 
Normalizing the use of these types of technologies may represent not only a gift to authoritarian governments but also a consolidation of the power of technology companies. ${ }^{115}$

It has been argued that quasi-compulsion around any sort of immunity certification process for access to certain facilities not only raises profound issues in relation to liberty and personal privacy but may also impact most significantly on those who fall at the margins of society, for example, those who struggle to access vaccines. ${ }^{116}$ There will also be cost issues, since in many countries this will mean-in the absence of vaccination-investing in a succession of tests for which there is a charge. Such "green pass" measures are an alternative to making vaccination mandatory, but, like mandatory vaccination, inevitably also raise legal concerns around the right to private life. The surge in numbers booking vaccination appointments in France after an announcement ${ }^{117}$ by President Macron that immunity certification would be required from August, 2021 for access to many public and private facilities, including bars and restaurants, highlights the potential effectiveness of such an approach. ${ }^{118}$ This goes well beyond the restrictive measures approved previously by France's Conseil constitutionnel in respect of participation in large gatherings. ${ }^{119}$ Unsurprisingly, the announcement also provoked a substantial backlash, which meant that the government softened the proposed scope of the scheme and the sanctions for non-compliance-which was probably a "price" already built into the scheme when it was announced ${ }^{120}$ —even though the Conseil d'Etat green-lighted the proposals in advice that was handed down prior to adoption. ${ }^{121}$ Although approved in the Assemblée nationale, the legislation to underpin the scheme was referred to the Conseil constitutionnel before it could enter into force. The Conseil constitutionnel found most of the provisions of the law, in particular those relating to the so-called passe sanitaire, to be in conformity with the constitution. ${ }^{122}$ An alternative model is provided by Israel's "green pass," the legislative basis for which disappeared within a few months, as it was introduced with a sunset clause and was not extended. ${ }^{123}$ Supporters of the green pass pointed out that such measures would always work best and be most likely to pass constitutional scrutiny if a legitimate purpose for their introduction could be identified and they were also subject to periodic review. ${ }^{124}$

The question of vaccination take-up became an urgent issue as soon it became apparent that highly effective vaccines were set to become a part of the international conversation about combatting COVID-19 from late 2020 onwards. Mandatory or effectively mandatory vaccinations for children against communicable diseases that can cause them or the people they come into contact with significant harm are quite common and have been recently upheld by the European Court of

\footnotetext{
${ }^{115}$ Naomi Klein, How Big Tech Plans to Profit from the Pandemic, GuARDIAN, May 13, 2020, https://www.theguardian.com/ news/2020/may/13/naomi-klein-how-big-tech-plans-to-profit-from-coronavirus-pandemic.

${ }^{116}$ Sarah Ganty, The Veil of the COVID-19 Vaccination Certificates: Ignorance of Poverty, Injustice Towards the Poor, 12 EUR. J. RISK REGUL. 343 (2021), https://doi.org/10.1017/err.2021.23.

${ }^{117}$ Mandatory Vaccination, Covid-19 Pass and Access to PCR Tests: The Main Points from Macron's Address, FrANCE24 (Jul. 12, 2021), https://www.france24.com/en/europe/20210712-follow-live-france-s-macron-addresses-the-nation-as-covid-19delta-variant-surges.

${ }^{118}$ Benedicte Sage Fuller, The Health Pass in French Legislation, The Constitution ProjeCt @ UCC (Aug. 2, 2021), http:// constitutionproject.ie/?p=812.

${ }^{119}$ Conseil constitutionnel [CC] [Constitutional Court] decision No. 2021-819DC, May 31, 2021 (Fr.), https://www.conseilconstitutionnel.fr/decision/2021/2021819DC.htm.

${ }^{120}$ Clea Caulcutt, France Forced to Soften Rules After Coronavirus Green Pass Backlash, Politico (Jul. 20, 2021) https:// www.politico.eu/article/france-rules-coronavirus-green-pass-vaccine-backlash/.

${ }^{121}$ Avis sur un projet de loi relatif à la gestion de la crise sanitaire, CONSEIL D’ÉTAT, (Jul. 20, 2021) https://www.conseil-etat.fr/ ressources/avis-aux-pouvoirs-publics/derniers-avis-publies/avis-sur-un-projet-de-loi-relatif-a-la-gestion-de-la-crise-sanitaire.

${ }^{122}$ See SHAW, supra note 25.

${ }^{123}$ E. Albin \& A. Gross, First In First Out: The Rise and Fall of Israel's Green Pass, LeX-ATLAS: COVID-19 (Jun. 2, 2021), https://lexatlas-c19.org/first-in-first-out-the-rise-and-fall-of-israels-green-pass/.

${ }^{124}$ Einat Albin \& Aeyal Gross, Israel: Is the "Green Pass" an Example to Follow?, LeX-AtLas: COVID-19 (May 7, 2021), https://lexatlas-c19.org/israel-is-the-green-pass-an-example-to-follow/; Tamar Luster, Einat Albin, Aeyal Gross, Miriam Tabenkin, \& Nadav Davidovitch, Promoting Vaccination from a Human Rights and Equity Perspective: Lessons from the Israeli “Green Pass,” 12 EUR. J. Risk Regul. 308 (2021).
} 
Human Rights (ECtHR) in the face of a challenge to a Czech requirement that for children to be admitted to school they must be vaccinated against nine specific diseases. This judgment, in a case which reached the ECtHR before the COVID-19 pandemic, could not have been more timely, and the case was "upgraded" to the Grand Chamber in the light of its potential future relevance. In essence, the ECtHR decided that making vaccination a requirement for access to educational facilities could be regarded as "necessary in a democratic society," although it concluded that the policy fell within the scope of the Article 8 protection of the right to private life. ${ }^{125}$ However, any interference with Article 8 rights had to be balanced against the state's positive duty to protect human life, and national decisions should be taken in the light of scientific consensus about the safety and efficacy of the vaccines in question, which comes into play in the context of the necessity and proportionality assessment of any mandatory vaccination policy.

Focused on the "standard and routine vaccination of children against diseases that are well known to medical science" and on indirect measures which penalize non-vaccination rather than state coercion in relation to bodily integrity, the case offers only limited analysis to guide how we should understand the legal treatment of COVID-19 vaccination in European states. ${ }^{126}$ However, it seems likely that a carefully circumscribed policy based on an enabling legislative measure, in line with scientific evidence and adopting a proportionate approach to the attainment of whatever objectives have been set, would probably be upheld by the ECtHR. Moreover, casting the net beyond Europe, the reasoning is quite closely aligned with several recent judgments of the Supreme Federal Tribunal of Brazil, which supported the constitutionality of compulsory but not coercive vaccination for COVID-19. ${ }^{127}$ Interestingly enough, however, the Inter-American Commission on Human Rights seems to have pointed in a different direction, by emphasizing in guidance issued that all vaccinations must be given on the basis of free and informed consent. ${ }^{128}$

So far, there appear to be relatively few examples of wide-ranging vaccine mandates put in place by states, other than for certain professions or as a condition for the exercise of certain privileges, for example, international travel or removal of quarantine requirements. ${ }^{129}$ However, there are a huge number of variables to be considered in relation to these issues. These include the extent of exemptions for sincerely held beliefs, the extent of trust in science in a given country, processes of social exclusion that mean that members of ethnic and racial minorities in many countries have lower access in practice to vaccinations, and the ethics of suggesting or mandating vaccinations for children, given that they are much less affected by COVID-19 and that the trial and approval

\footnotetext{
${ }^{125}$ Vavřička v. Czech Republic, App. No. 47621/13 (Apr. 8, 2021), http://hudoc.echr.coe.int/eng?i=001-209039.

${ }^{126}$ See Katarzyna Ważyńska-Finck, Anti-vaxxers Before the Strasbourg Court: Vavřička and Others v. The Czech Republic, Strasbourg ObSERVERS Blog (Jun. 2, 2021), https://strasbourgobservers.com/2021/06/02/anti-vaxxers-before-thestrasbourg-court-vavricka-and-others-v-the-czech-republic/; Katsoni Spyridoula, What Does the Vavrička Judgement Tell Us About the Compatibility of Compulsory COVID-19 Vaccinations with the ECHR?, VÖLKERRECHTSBLOG (Apr. 21, 2021); Zuzana Vikarská, Is Compulsory Vaccination Compulsory?, VerfassungsBloG (Apr. 12, 2021), https://verfassungsblog.de/ is-compulsory-vaccination-compulsory/; David Archard, Joe Brierley \& Emma Cave, Compulsory Childhood Vaccination: Human Rights, Solidarity, and Best Interests, MED. L. Rev., 2021, https://doi.org/10.1093/medlaw/fwab024; Marthe Goudsmit, Mandatory Vaccination and the Infringement of Children's Article 8 Rights for Their Parents' Non-compliance, 43 J. Soc. Welfare AND FAM. L. 335 (2021), https://doi.org/10.1080/09649069.2021.1953853; Natalie Grubb, What Does the European Court of Human Rights (ECtHR) Ruling on Compulsory Vaccination Mean for Our Human Rights in the UK?, BRITISH INST. HUM. RTS. BLOG, https://www.bihr.org.uk/blog/what-does-the-european-court-of-human-rights-ecthrruling-on-compulsory-vaccination-mean-for-our-hum.

${ }^{127}$ Octávio Luiz Motta Ferraz, Brazil: Compulsory (But Not Forced) Vaccination Is Constitutional, Says Supreme Federal Tribunal, LEX-ATLAS: COVID-19 (Apr. 29, 2021), https://lexatlas-c19.org/compulsory-but-not-forced-vaccination-isconstitutional-says-brazilian-supreme-federal-tribunal/.

${ }^{128}$ Inter-Am. Ct. H.R., COVID-19 Vaccines and Inter-American Human Rights Obligations, Resolution No. 1/2021, Apr. 6, 2021.

${ }^{129}$ Blog Symposium on Mandatory Vaccination, LEX-ATLAS: COVID-19, https://lexatlas-c19.org/tag/mandatoryvaccinations-blog-symposium/; Jeff King \& Octávio Luiz Motta Ferraz, Legal, Constitutional and Ethical Principles for Mandatory Vaccination Requirements for Covid-19, (Oct. 29, 2021), https://lexatlas-c19.org/legal-constitutional-andethical-principles-for-mandatory-vaccination-requirements-for-covid-19/?s=09.
} 
processes for these vaccines have been taken less time than ever before in modern medical history. Exactly how any given polity parses the balance of interests between the collective and the individual is likely to be a function of specific national or other contexts. An argument for the application of the principle of Ubuntu - or an ethic of care and respect for humanity - in the context of the application of South African constitutional rights to the question of vaccination nicely illustrates the latter point. ${ }^{130}$ These are ethical questions, for sure, but also questions about what we owe each other in a specific social context, not as a matter of ideal theory or in view of universal principles, but in practical terms. For these purposes, rationalizing decision-making in relation to intrusions into private life within a framing of citizenship as social membership is a productive approach. It offers a clear pathway to understanding how these interests can best be balanced against each other, whilst at the same time adopting an intersectional analysis which takes into consideration differential vaccination rates between different social and ethnic groups, given that these often stem from unequal access as well as distrust of the state and medical institutions.

\section{F. The Side-lining of Democracy: The Challenge of Oversight of Decision-making in a Crisis for Citizens and Their Representatives}

Given the centrality of political citizenship and associated civil liberties, such as freedom of expression and of assembly, to the constitutional and democratic foundations of many polities, framing key questions about the impact of the pandemic in the political domain in terms that combine citizenship and constitutional principles is both an important and a relatively straightforward task. Political citizenship is intimately connected with questions of political participation and the legitimacy of decision-making. It is vital, therefore, to explore this issue in the context of a syndemic analysis of COVID-19.

For example, the pandemic has the capacity to interrupt the normal lines of political participation. It can do this through its impact on elections and campaigning and other similar episodic events such as referendums. ${ }^{131}$ It may also disrupt both non-violent civil resistance or protest as an expression of citizenship ${ }^{132}$ and armed conflict aimed at political change, ${ }^{133}$ if individuals and groups can no longer safely gather in person because of fears of contagion. A number of observatories have been tracking the impacts of the pandemic on all aspects of the political process, including comparing the incidence of protest and conflict during the pandemic to the period immediately before as well as assessing the measures taken either to support or to repress political action. ${ }^{134}$ Early findings, based thus far largely on anecdotal evidence, seemed to indicate a

${ }^{130}$ Tanya Calitz, Constitutional Rights in South Africa Protect Against Mandatory COVID-19 Vaccination, HEALTH AND Hum. RTS. J. BlOG (Apr. 21, 2021), https://www.hhrjournal.org/2021/04/constitutional-rights-in-south-africa-protectagainst-mandatory-covid-19-vaccination/.

${ }^{131} \mathrm{See}$, e.g., the highly politicized referendum in Chile on whether to draft a new Constitution replacing the Pinochet-era constitution that was postponed from April, 2020, until October, 2020, as a result of the pandemic. This referendum was intended to build upon the widespread protests that occurred in Chile in the latter months of 2019, and the process should, as agreed in the referendum, include a high level of citizen participation and involvement involving an elected constituent assembly, and some now fear that the momentum towards reform has dissipated because of the conditions caused by the pandemic. See, for discussion and background, Alexander Hudson \& Rodolfo Disi Pavlic, The Constitutional Reform Referendum in Chile: Balancing Democracy and Elite Accommodation, INT'L Const. L. BLOG (Sep. 23, 2020), http://www. iconnectblog.com/2020/09/the-constitutional-reform-referendum-in-chile-balancing-democracy-and-elite-accommodation/.

${ }^{132}$ Erica Chenoweth, The Future of Nonviolent Resistance, 31(3) J. DEMOCRACY 69 (2020).

${ }^{133}$ Melissa Pavlik, A Great and Sudden Change: The Global Political Violence Landscape Before and After the COVID-19 Pandemic, ACLED (Aug. 4, 2020), https://acleddata.com/2020/08/04/a-great-and-sudden-change-the-global-politicalviolence-landscape-before-and-after-the-covid-19-pandemic/.

${ }^{134}$ For example, COVID-19 Disorder Tracker, ACLED, https://acleddata.com/analysis/covid-19-disorder-tracker/; Global Protest Tracker, CARNEGIE ENDOWMENT FOR INT'L PEACE, https://carnegieendowment.org/publications/interactive/protesttracker; Democracy During Pandemic, FreEdom House, https://freedomhouse.org/issues/democracy-during-pandemic; Global State of Democracy Indices, INTERNATIONAL IDEA, https:/www.idea.int/gsod-indices/\#/indices/world-map; on 
substantial rapid drop in all types of protest activities as soon as the pandemic took hold and lockdowns were established, followed by a subsequent rise. ${ }^{135}$ Based on the analysis of previous pandemics and epidemics, this is the pattern that is to be expected. However, over the longer term, the intersections between conflicts related to the pandemic itself and the existing areas of political conflict that engender protest are likely to be complex. ${ }^{136}$ The same can be said of civic and political engagement within democracies, where early evidence highlights that pandemic conditions largely reproduce existing political inequalities, although threat perceptions in relation to the ongoing challenge of the pandemic may be giving rise to changed patterns of engagement and protest. ${ }^{137}$

There are clearly practical problems involved in running elections during a pandemic. These are well exemplified by the case of Croatia, where the Constitutional Court held that it was constitutional for measures to be taken to restrict access to voting in person in the case of those who had tested positive for COVID-19 and to make alternative arrangements for them to vote. ${ }^{138}$ In view of the inevitable levels of disruption, the question arises as to whether it is more or less democratic to go ahead with the election or to postpone it. ${ }^{139}$ The holding of elections is likely, at the very least, to be more expensive than in "normal times," given the costs of social distancing and other measures to protect voters, candidates, and poll workers. ${ }^{140}$ The usual integrity and fairness problems regarding information around elections and campaigning are bound to arise-including access to broadcast and print media — and it is clear that the pandemic raises the stakes around issues of "truth" and makes the relationship between scientific expertise and political communications more complex than ever. ${ }^{141}$ Singapore offers an interesting example of a country where elections went ahead despite the pandemic, and where some of the changed conditions brought about by the pandemic, including a greater degree of interaction between citizens and state authorities, may have led to greater democratic consolidation. ${ }^{142}$ In the Vienna City Elections,

governmental responses to COVID-19, see COVID-19 Government Response Tracker, UNIV. OxFORD, https://www.bsg.ox.ac. uk/research/research-projects/covid-19-government-response-tracker; COVID-19 Civic Freedom Tracker, ICNL \& ECNL, https://www.icnl.org/covid19tracker; Global Democracy \& Pandemic Tracker, DEM-DEC, https://www.democratic-decay. org/covid-dem.

${ }^{135}$ Christopher McCrudden, Democracy, Protests, and Covid-19: The Challenge of (and for) Human Rights, UK CONST. L. BLOG (Jun. 19, 2020), https://ukconstitutionallaw.org/2020/06/19/christopher-mccrudden-democracy-protests-and-covid-19the-challenge-of-and-for-human-rights/.

${ }^{136}$ Roberto Censolo \& Massimo Morelli, COVID-19 and the Potential Consequences for Social Stability, 26(3) PEACE ECON., Peace SCI. ANd Pub. Pol'y 20200045 (2020).

${ }^{137}$ Endre Borbáth, Sophia Hunger, Swen Hutter, \& Ioana-Elena Oana, Civic and Political Engagement During the Multifaceted COVID-19 Crisis, 27 Swiss POL. SCI. Rev. 311 (2021).

${ }^{138}$ Judgment of the Constitutional Court of Croatia of July 3, 2020, U-VII-2980/2020. For summary, see CounCIL OF EUROPE, CODICES, http://www.codices.coe.int./.

${ }^{139}$ For detailed data, see Global Overview of COVID-19: Impact on Elections, INTERNATIONAL IDEA, https://www.idea.int/ news-media/multimedia-reports/global-overview-covid-19-impact-elections. Toby S. James \& Sead Alihodzic, When Is It Democratic to Postpone an Election? Elections During Natural Disasters, COVID-19, and Emergency Situations, 19(3) Election L.J. 344 (2020); Todd Landman \& Luca Di Gennaro Splendore, Pandemic Democracy: Elections and COVID19, 23(7-8) J. Risk RsCH. 1060 (2020). Reviewing some of the international practice, see Graeme Orr, Voting in a Pandemic: Lessons from International Experience, GLOBALCIT (May 6, 2020), https://globalcit.eu/voting-in-a-pandemiclessons-from-international-experience/. On the specific case of the US elections in November 2020, see Richard L. Hasen, Three Pathologies of American Voting Rights Illuminated by the COVID-19 Pandemic, and How to Treat and Cure Them, 19(3) Election L.J. 263 (2020).

${ }^{140}$ Christopher R. Deluzio, Elizabeth Howard, David Levine, Paul Rosenzweig, \& Derek Tisler, Ensuring Safe Elections: Federal Funding Needs for State and Local Governments During the Pandemic, Brennan CTr. Just., (Apr. 30, 2020), https://securingdemocracy.gmfus.org/wp-content/uploads/2020/05/Ensuring-Safe-Elections.pdf.

${ }^{141}$ For a general argument about the relationship between truth and democracy, see Sten Hansson \& Sandra Kröger, How a Lack of Truthfulness Can Undermine Democratic Representation: The Case of Post-referendum Brexit Discourses, BRITISH J. POL. AND INT'L RELS, (Dec. 14, 2020).

${ }^{142}$ Shirin Chua \& Jaclyn L. Neo, COVID-19 as an Opportunity for Democratic Consolidation? Law, Politics, and Citizen-State Interactions in Singapore, VERFBLOG (Feb. 24, 2021), https://verfassungsblog.de/covid-19-as-an-opportunity-for-democraticconsolidation/. 
held during the pandemic, voters moved decisively away from far right-wing parties using populist rhetoric and engaging with misinformation about the pandemic. ${ }^{143}$ In France, however, research has shown that lower participation levels in municipal elections correlate with factors such as age, which is an important indicator of COVID-19 vulnerability. ${ }^{144}$ In other words, vulnerability to COVID-19 may increase abstentionism amongst voters.

Of fundamental importance to the evolution of constitutionalism more generally are the effects of the pandemic on the legislative-executive-judicial balance and on the separation of powers. ${ }^{145}$ As Bonnie Honig reminds us, "Enacting or exacting accountability is one of the essential responsibilities of democratic citizenship." 146 In that respect, the COVID-19 crisis has clearly engendered significant challenges to both democratic principles and democratic performance. ${ }^{147}$ Certainly in the early days of the pandemic, decisions had to be taken in great haste and emergency powers were often invoked. One early assessment warned of a pandemic of authoritarianism as a result of the flood of emergency measures. ${ }^{148}$ Indeed, it is not difficult to mount an argument that excessive reliance upon executive action on the grounds that it is needed in an emergency may encourage further authoritarian responses and may lead to long term democratic degradation. It is unfortunate that this should occur at a moment when democracy seems already to be under significant threat in many countries in an age of populist politics. ${ }^{149}$ The pandemic has been described as an "inflection point" for democracies already under stress. ${ }^{150}$ Yet at the same time, as the rich country-based data gathered by several projects/observatories ${ }^{151}$ and the preliminary comparative research now available ${ }^{152}$ both highlight, it would be incorrect to generalize or to draw firm conclusions about what the implications of the pandemic for democracy might be, or whether it can be said that democracies or autocracies have performed better in relation to combatting the pandemic. ${ }^{153}$ The balance is changing over time, and also between countries. The evidence points in different directions and may be contradictory. ${ }^{154}$ Furthermore, it is not only the formal governmental institutions that are relevant here, but also the inputs of scientific experts ${ }^{155}$ and of non-governmental organizations and levels of trust in particular countries in both science and

\footnotetext{
${ }^{143}$ Viennese Voters Turn Their Backs on Populist Freedom Party, FIn. TimEs (Oct. 12, 2020), https://www.ft.com/content/ 96f211e4-3494-4e55-b124-98729c53c765.

${ }^{144}$ Abdul Noury, Abel Francois, Oliver Gergaud \& Alexandre Garel, How Does COVID-19 Affect Electoral Participation? Evidence from the French Municipal Elections, 16(2) PLOS ONE e0247026 (2021).

${ }^{145}$ For examples of democratic and judicial oversight, as well as more problematic cases, see Alice Donald \& Philip Leach, Human Rights and COVID-19: Forging Recovery After a Pandemic of Abuses?, VerfBlog (Apr. 10, 2021), https:// verfassungsblog.de/human-rights-and-covid-19-forging-recovery-after-a-pandemic-of-abuses/.

${ }^{146}$ Bonnie Honig, Emergency Politics: Paradox, Law, Democracy, 69 (Princeton Univ. Press 2009).

${ }^{147}$ Klaus H. Goetz \& Dorte Sindbjerg Martinsen, COVID-19: A Dual Challenge to European Liberal Democracy, 44(5-6) W. EUR. POL. 1003 (2021).

${ }^{148}$ Stephen Thomson \& Eric C. Ip, COVID-19 Emergency Measures and the Impending Authoritarian Pandemic, 7(1) J.L. \& BIosCIs. (2020), https://www.ncbi.nlm.nih.gov/pmc/articles/PMC7543595/.

${ }^{149}$ Autocratization Turns Viral: Democracy Report 2021, UnIV. Gothenburg V-Dem Inst. (2001), https://www.v-dem.net/ files/25/DR\%202021.pdf.

${ }^{150}$ Amit Prakash, Shadow of the Pandemic and the Beleaguered Liberal-Democratic Script in India, 20:2 INDIA REV. 104 (2021).

${ }^{151}$ See supra note 1 . For executive accountability to parliament. See also Univ. BIRmingham, The COVID-19 ReviEw OBSERVATORY, https://www.birmingham.ac.uk/research/artslaw/projects/cvro.aspx. See also other individual case studies, such as Jan Petrov, The COVID-19 Emergency in the Age of Executive Aggrandizement: What Role for Legislative and Judicial Checks?, 8:1-2 TheOry \& Practice Legis. 71 (2020).

${ }^{152}$ For example, Maritza Lozano, Michael Atkinson, \& Haizhen Mou, Democratic Accountability in Times of Crisis: Executive Power, Fiscal Policy and COVID-19, Gov'T \& Opposition (2021).

${ }^{153}$ Tom Gerald Daly, Democracy and the Global Pandemic: Reshuffled Reputations and the Future of the "Free World," VerfassungsBlog (May 1, 2021), https://verfassungsblog.de/democracy-and-the-global-pandemic/.

${ }^{154}$ Afsoun Afsahi, Emily Beausoleil, Rikki Dean \& Selen A. Ercan, Democracy in a Global Emergency, 7(2) DEMOCRATIC THEORY (2020).

${ }^{155}$ Andrea Lavazza \& Mirko Farina, The Role of Experts in the Covid-19 Pandemic and the Limits of Their Epistemic Authority in Democracy, Frontiers Pub. Health 8 (2020).
} 
politics that operate as key variables. This is an issue which will require careful monitoring over the longer term for clearer comparisons to be drawn of "before" and "after," or across countries, regions, continents, or regime types. Further work will need to be done to calibrate across the issues of inequality and vulnerability which are central to the analysis in this article. It will be some time before we can see clearly the extent to which the degradation of democratic citizenship amidst the pandemic may correlate to or even cause the adoption of measures that either undermine or protect certain vulnerable groups in relation to how the pandemic impacts upon them.

\section{G. Protecting the Vulnerable in a Pandemic}

Where previous sections have discussed how the syndemic (that is to say, the health and the socioeconomic) impacts of COVID-19 in relation to citizenship have had a disproportionate impact on certain groups, this final substantive section of the paper places those same groups at the center of the analysis by asking how best we can protect the vulnerable in a pandemic and in the recovery from a pandemic. One of the primary critiques of citizenship is that it promises but does not deliver equality, and that this failure to match promise and reality has particularly damaging consequences for certain groups defined by their "vulnerability." 156 Those groups include those within the polity who find themselves unable to articulate an effective claim to "full membership" because they belong to a marginalized group or minority, as well as those who fall foul of the arbitrary and often coercive boundaries of the state-based membership status and for whom any protection provided under international law is also often rather sparse. Some groups, such as migrant care workers, for example, cut across both categories of the excluded. ${ }^{157}$ Of course, it is clear that human rights norms, both internally and in terms of international law, can be useful tools in terms of contesting failures to protect effectively those with additional vulnerabilities to the effects of the pandemic within states and across the world. ${ }^{158}$ It is, however, also fruitful to think about the contestation of vulnerability in terms of constitutional citizenship.

For example, concepts of social citizenship buttressed by constitutional rights such as those protecting health or human dignity, as well as the right to life, could be brought into play to develop the argument that responses to the pandemic require a new type of social contract that prioritizes the protection of those who are more vulnerable to the effects of the virus. ${ }^{159}$ This has been a consistent theme of the scholarship on the pandemic which has sought to look forward rather than simply commenting on contemporaneous events. What is needed is work which goes beyond compiling a laundry list of protective measures and which moves towards adopting more holistic approaches. Such approaches need to weigh the cost of different measures for different groups, and to consider not only the classic binary of libertarian and authoritarian approaches to the scope of restrictions imposed in the interests of health and life but also the fundamentally social democratic nature of the protection of public health. ${ }^{160}$ This way of valuing public health protection stands in contradistinction to the powerful neoliberal ethos that has dominated most socio-economic debates in recent years. ${ }^{161}$ A social democratic analysis can give communities the

\footnotetext{
${ }^{156}$ For a fuller understanding of "vulnerability" and its contested nature, see the references cited supra note 20.

${ }^{157}$ Sonja Avlijaš, Security for Whom? Inequality and Human Dignity in Times of the Pandemic, in PANDEMICS, POL., \& SOC'Y 227, (Gerard Delanty ed., De Gruyter 2021).

${ }^{158}$ See, e.g., thinking about rights to an effective healthcare system, Lisa Forman \& Jillian Clare Kohler, Global Health and Human Rights in the Time of COVID-19: Response, Restrictions, and Legitimacy, 19:5 J. HuM. RTS. 547 (2020).

${ }^{159}$ See, e.g., the contributions to Democracy in Times of PANDEMic: Different Futures Imagined (Miguel Poiares Maduro \& Paul W. Kahn eds., Cambridge Univ. Press 2020).

${ }^{160}$ Sylvia Walby, The COVID Pandemic and Social Theory: Social Democracy and Public Health in the Crisis, 24 EUR. J. Soc. THEORY 22 (2021)

${ }^{161}$ Bram Büscher, Guiseppe Feola, Andrew Fischer, Robert Fletcher, Julien-Francois Gerber, Wendy Harcourt, Martijn Koster, Mindi Scheider, Joeri Scholtens, Marja Spierenburg, Vincent Walstra \& Han Wiskerke, Planning for a World Beyond COVID-19: Five Pillars for Post-neoliberal Development, 140 WorLd Dev. 105357 (2021).
} 
tools to resist the inevitability that those who have suffered most from the pandemic should also "pay" for it through austerity, as happened after the financial crisis of 2008 onwards. That these communities have indeed paid can be demonstrated by the calculations of researchers who have estimated that there have been tens of thousands of preventable deaths from austerity just in the UK. ${ }^{162}$

One further advantage of a citizenship rather than human rights framing for future-focused arguments about protecting the vulnerable is that it fosters a focus on obligations as well as rights. In other words, a revived and potentially constitutionalized conception of social citizenship can be used to justify restrictions on individual freedoms in the collective interest but in such a way that pays special attention to the vulnerable. For example, a mask mandate may seem to be a straightforward way of reducing risk, especially indoors. ${ }^{163}$ Yet certain groups, such as those with hearing difficulties or asthma, or others who have faced previous trauma around suffocation, may find themselves marginalized by a mask mandate applied without regard to their specific interests. Designing sensitive policies needs to engage policymakers and other stakeholders. Courts cannot be the primary actors as there would be limits to the extent that they could effectively intervene in areas requiring complex policy solutions, except to prevent egregious interferences with individual freedoms or to protect specific groups whose interests have been left out of the policy-making process. That said, there have already been examples where courts have engaged constructively in the contestation of similar political choices, for example, in a federal context in Brazil. ${ }^{164}$

An obligations approach can also be supplemented by a principle of gratitude, which can be seen in some countries that have taken steps to give permanent residence to frontline workers in precarious situations. ${ }^{165}$ As an emotion, gratitude has been brought to the fore, as shown by examples such as "clap for carers" and other measures taken in the UK and elsewhere to express thanks to those who have taken on an outsize level of risk during the pandemic. This was especially salient at the outset of the pandemic, when the risks were not well understood and there was a shortage of personal protective equipment. But, later on, emotions have spilled over into anger at the failure of public authorities to translate gratitude into concrete steps to reward at-risk groups. ${ }^{166}$ One sign of a broken social contract is a requirement that workers isolate themselves if they have tested positive or come into contact with someone who has tested positive, and yet they are not provided comprehensive sick pay coverage to prevent personal financial loss. Across the world, the pandemic has reworked concepts of risk and skill such that it could be conceivable to develop new frames of deservingness that do not replicate the pitfalls of current approaches and that can decrease rather than increase the effects of marginalization. ${ }^{167}$ These are the raw materials on the basis of which societies can truly "build back better."

\section{H. Conclusions}

This article has begun the task of outlining the impacts of the pandemic in matters of citizenship using a syndemic analysis placing both the pandemic and the ideas and practices of citizenship in their wider contexts. It sets the scene for more detailed research in the future. While the scope of

\footnotetext{
${ }^{162}$ Dean Hochlaf, Harry Quilter-Pinner \& Tom Kibasi, Ending the Blame Game: The Case for a New Approach to Public Health and Prevention, IPPR (Jun. 4, 2019), https://www.ippr.org/files/2019-06/public-health-and-prevention-june19.pdf.

${ }^{163}$ Trisha Greenhalgh, Face Coverings for the Public: Laying Straw Men to Rest, 26 J. Evaluation CliniCAL PraC. 1070 (2020).

${ }^{164}$ João Biehl, Lucas E.A. Prates \& Joseph J. Amon, Supreme Court v. Necropolitics: The Chaotic Judicialization of COVID-19 in Brazil, 23 Health \& Hum. RTs. J. 151 (2021).

${ }^{165}$ Mollie Gerver, The Case for Permanent Residency for Frontline Workers, AM. POL. ScI. Rev. (2021).

${ }^{166}$ Helen Wood \& Beverley Skeggs, Clap for Carers? From Care Gratitude to Care Justice, 23(4) EUR. J. CULTURAL STUD. 641 (2020).

${ }^{167}$ Maike Isaac \& Jennifer Elrick, How COVID-19 May Alleviate the Multiple Marginalization of Racialized Migrant Workers, 44 ETHNIC \& RACIAL STUD. 851 (2021).
} 
the review has often been quite broad and encompasses so many different domains of "pandemic life," it is interesting to see how many of these impacts do in fact operate at the intersection of citizenship and constitutional law and thus play out in the form of changes in relation to constitutional citizenship. Accordingly, the article takes an important step towards the use of constitutional citizenship as a framing device for understanding citizenship as full membership. It also moves the debate further onto normative terrain by considering the extent to which articulating a substantive concept of constitutional citizenship through a focus on the principles of equality, human dignity and freedom provides a constitutional and legal reference point.

An important leitmotiv used throughout the article has been the idea of the "linear" and probably inevitable impacts of the pandemic on citizenship. That is one area, perhaps, where the "benchmarking" approach to the evaluation of policy may be of some assistance, ${ }^{168}$ although the complexity of thinking about COVID-19 through the prism of citizenship reinforces the risks of thinking about the pandemic as "just" a policy problem to be "solved." In fact, the pandemic has revealed itself to be full of paradoxes. ${ }^{169}$ The article has also taken on the task of exploring how and why, in some domains, these impacts are further shaped by factors such as vulnerability and inequality of outcomes. It is clear that the synergistic or intersectional thinking encouraged by the characterization of the pandemic as a syndemic, which links together health, socio-economic issues, and political questions, is useful for highlighting how much more vulnerable to many of the negative impacts of the pandemic in the sphere of citizenship are those who are also more vulnerable both to catching and suffering more seriously from the virus and to experiencing negatively the externalities of the measures taken to restrict social contact by shutting down economies. The linear impacts of the virus on citizenship are substantially conditioned by issues of equality and inequality while at the same time suggesting some of the contours of how to "build back better" by thinking harder about solidarities. ${ }^{170}$

\footnotetext{
${ }^{168}$ See, e.g, Sheila Jasanoff \& Stephen Hilgartner, A Stress Test for Politics: Insights from the Comparative Covid Response Project (CompCoRe) 2020, VERFBLOG (May 11, 2021), https://verfassungsblog.de/a-stress-test-for-politics-insights-from-thecomparative-covid-response-project-compcore-2020/.

${ }^{169}$ Peter G. Danchin, The Pandemic Paradox in International Law, 114 AM. J. INT'L L. 598 (2020).

${ }^{170}$ See e.g., Kristin van Barneveld, Michael Quinlan, Peter Kriesler, Anne Junor, Fran Baum, Anis Chowdhury, PN Junakar, Stephen Clibborn, Frances Flanagan, Chris Wright, Sharon Friel, Joseph Halevi \& Al Rainnie, The COVID-19 Pandemic: Lessons on Building More Equal and Sustainable Societies, 31 Econ. \& LAB. Rels. Rev. 133 (2020); Katharine G. Young, The Idea of a Human Rights-Based Economic Recovery after COVID-19, 6(4) INT'L J. PUB. L. \& POL'y 390 (2020).
}

Cite this article: Shaw J (2021). Citizenship and COVID-19: Syndemic Effects. German Law Journal 22, 1635-1660. https:// doi.org/10.1017/glj.2021.77 